Review

\title{
Polyunsaturated fatty acids in the central nervous system: evolution of concepts and nutritional implications throughout life
}

\author{
Jean-Marc ALESSANDRI ${ }^{\mathrm{a} *}$, Philippe GUESNET ${ }^{\mathrm{a}}$, Sylvie VANCASSEL ${ }^{\mathrm{a}}$, \\ Pierre ASTORG ${ }^{\mathrm{b}}$, Isabelle DENIS ${ }^{\mathrm{a}}$, Bénédicte LANGELIER ${ }^{\mathrm{a}}$, Sabah AÏD ${ }^{\mathrm{a}}$, \\ Carine POUMÈs-BALLIHAUT ${ }^{\mathrm{a}}$, Gaëlle CHAMPEIL-POTOKAR ${ }^{\mathrm{a}}$, \\ Monique LAVIALLE ${ }^{\mathrm{a}}$ \\ a Neurobiologie des Lipides, Laboratoire de Nutrition et Sécurité Alimentaire, INRA, \\ 78352 Jouy-en-Josas, France \\ ${ }^{\mathrm{b}}$ UMR 557 INSERM/INRA/CNAM Épidémiologie Nutritionnelle, Institut Scientifique et Technique \\ de la Nutrition et de l'Alimentation, CNAM, 5 rue du Vertbois, 75003 Paris, France
}

(Received 18 June 2004; accepted 10 September 2004)

\begin{abstract}
Docosahexaenoic acid (DHA, 22:6n-3) and arachidonic acid (AA, 20:4n-6) are the major polyunsaturated fatty acids in the membranes of brain and retinal cells. Animals specifically deficient in dietary n-3 fatty acids have low DHA content in their membranes, reduced visual acuity and impaired learning ability. Studies on bottle-fed human infants have shown that adding DHA and AA to milk replacer-formulas can bring their concentrations in the infant blood lipids to values as high as those produced by breast-feeding and significantly improves mental development and maturation of visual function. In older subjects, diverse neuropsychiatric and neurodegenerative diseases have been associated to decreased blood levels of n-3 PUFA. Low intakes of fish or of n-3 PUFA in populations have been associated with increased risks of depression and Alzheimer disease, and n-3 PUFA, especially eicosapentaenoic acid (EPA, 20:5n-3), have shown efficacy as adjunctive treatment - and in some cases as the only treatment - in several psychiatric disorders. The mechanisms by which polyunsaturated fatty acids have an impact on neuronal functions will be reviewed: the modulation of membrane biophysical properties, regulation of neurotransmitter release, synthesis of biologically active oxygenated derivatives, and nuclear receptor-mediated transcription of genes responsive to fatty acids or to their derivatives.
\end{abstract}

docosahexaenoic acid / arachidonic acid / retina / brain / milk feeding / eicosanoids / synaptic terminals / phototransduction / neuroprotection / nuclear receptors / neuropsychiatric diseases / neurodegenerative diseases

\begin{abstract}
Abbreviations
AA: arachidonic acid (20:4n-6), ABC: ATPbinding cassette transporters, ACS2: acylCoAsynthase 2, ADHD: attention-deficit hyperactivity disorders, AFSSA: Agence Française de Sécurité Sanitaire des Aliments, AOX: peroxi-
\end{abstract}

somal acylCoA-oxidase, aP2: adipocyte lipidbinding protein 2, ApoE: apolipoprotein E, BFABP: brain fatty acid-binding protein, $C A R \beta$ constitutive androstane receptor $\beta$, CD36: type $\mathrm{B}$ scavenger receptor, CNS: central nervous system, COUP-TF1: chicken ovalbumin upstream promoter-transcription factor 1, COX1 and COX2:

* Corresponding author: Jean-Marc.Alessandri@jouy.inra.fr 
cyclo-oxygenases 1 and 2, CYP2B: cytochrome P450-2B, DHA: docosahexaenoic acid (22:6n-3), DGLA: dihomo- $\gamma$-linolenic acid (20:3n-6), DHAmax: plateau value of DHA content in membrane phospholipids, DHA50: dietary dose of DHA required to reach half the DHAmax, DPA: docosapentaenoic (22:5n-6 or 22:5n-3), EPA: eicosapentaenoic acid (20:5n-3), ERG: electroretinogram, 8s-HETE: 8s-hydroxyeicosatetraenoic acid, HMG-CoAS: mitochondrial hydroxy-methyl-glutarylCoA synthase, HNF-4: hepatocyte nuclear factor-4, 3-KAT2: 3-keto acylCoA thiolase 2, LA: linoleic acid (18:2n-6), $\alpha$-LNA: alpha-linolenic acid (18:3n-3), 5- and 15-LOX: 5- and 15-lipoxygenases, L-PBE: Lperoxisomal bifunctional enzyme, LTB4: leukotriene B4, LXR: liver X receptor, NFkB: nuclear factor $\mathrm{KB}$, NPD1: "neuroprotectin D1", PBREM: phenobarbital responsive enhancer module, PE: phosphatidylethanolamines, PEPCK: phosphoenolpyruvate carboxykinase, 15d-PGJ2: 15-deoxy prostaglandin J2, PLA2: phospholipase A2, PP: peroxisome proliferators, PPAR: peroxisome proliferators-activated receptors, PPRE: peroxisome proliferator-responsive element, PTE-1b: peroxisomal thioesterase 1b, PUFA: polyunsaturated fatty acids, 9c-RA: 9cis retinoic acid, RAR: retinoic acid receptor, RXR: 9cis-retinoid $\mathrm{X}$ receptor, SREBP-1c: sterol regulatory element binding protein $1 \mathrm{c}, \mathrm{SCD}$ : stearoyl-CoA desaturase, UCP: uncoupling proteins.

\section{ESSENTIAL POLYUNSA- TURATED FATTY ACIDS (PUFA) IN THE FOOD CHAIN: ANIMALS NEED 20 AND 22 CARBON ATOMS, PLANTS SUPPLY ONLY 18}

The incorporation of polyunsaturated fatty acids (PUFA) in the nerve cell membranes of the brain and retina is one of the processes of perinatal development that contributes to the functional maturation of the central nervous system (CNS). In vertebrates, two major PUFA contribute to the framework of the nerve cell membranes, arachidonic acid (AA, 20:4n-6) and docosahexaenoic acid (DHA, 22:6n-3). The preferential incorporation of DHA in the brain and retina, as compared to other tissues, is a remarkable constant throughout the evolution of species. AA is the main long-chain derivative of the precursor of the $n-6$ series of essential fatty acids, linoleic acid (LA, 18:2n-6), whereas DHA is formed from the precursor of the $\mathrm{n}-3$ series, alpha-linolenic acid ( $\alpha$-LNA, 18:3n-3) (see review in [1]) (Fig. 1). Both precursors, which are themselves very minor constituents of the nerve cell membranes, are synthesised in variable proportions by plants, algae, bacteria and fungi, but not by vertebrate animals. In most animals, and some algae, bacteria and fungi, but not in plants, LA and $\alpha$-LNA are transformed into long chain PUFA, including which AA and DHA, respectively (Fig. 1). Thus, the concentration of AA and DHA in animal tissues and animal fats depends, in part, on the intake of precursors contained in foods. Man and omnivorous and carnivorous animals can directly ingest AA and DHA from animal preys or foods, whereas herbivorous animals exclusively depend on the supply of precursors, LA and $\alpha$-LNA.

Starting in the 1970s, the development of animal models specifically deficient in $n-3$ fatty acids, using vegetable oils very rich in LA and very poor in $\alpha$-LNA [2], has allowed the discovery of the essential role of DHA in the maturation of visual [3] and cerebral functions [4]. In n-3 PUFA deficient animals, alterations of retinal and brain functions are accompanied by a decrease in retinal and cerebral concentrations of DHA and by its replacement in tissue lipids by an n-6 long-chain PUFA, docosapentaenoic acid (n-6 DPA, 22:5n-6) (Fig. 1). This structural replacement is possibly related to the functional alterations observed in $\mathrm{n}-3$ deficient animals, with one of the most thoroughly investigated being that which occurs during the development of visual acuity.

\section{DHA, AN ESSENTIAL FACTOR IN THE MATURATION OF VISUAL ACUITY}

In rodents and in the rhesus monkey, a chronic dietary deficiency in n-3 fatty acids, i.e. starting from conception and continuing after birth and weaning, induces a sharp 


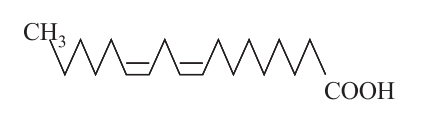

\section{$18: 2 n-6$}

$\bigwedge_{3} \sim \wedge M^{\mathrm{COOH}}$

Dihomo- $\gamma$-linolenic acid (DGLA)

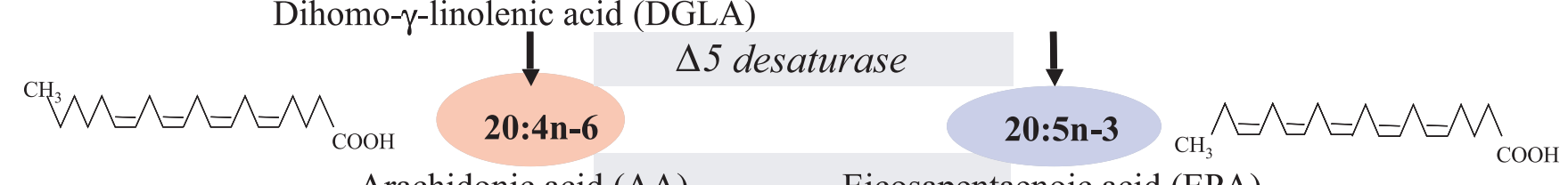

Arachidonic acid (AA)

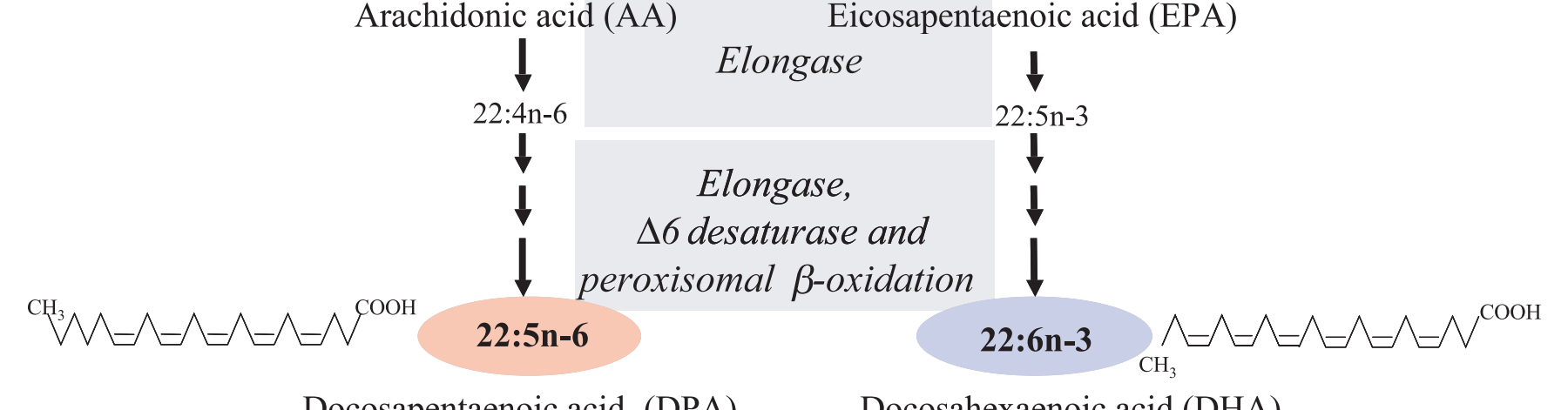

Docosahexaenoic acid (DHA)

Figure 1. Fatty acid metabolism of essential fatty acids of the n-6 and n-3 series via the elongation-desaturation pathway (based on data reviewed in [1]). 
decrease (from 50 to $80 \%$ ) of the DHA concentration in nerve cells and results in impairments of cerebral and visual functions [4-6]. Cerebral performances have been evaluated in rodents by their capacity to elaborate and memorise a stress-escape procedure (electrical shock [4]), or to perform in an elevated plus-maze or in a water maze [7]. Their visual performances have been determined by electroretinography (ERG) $[3,4]$. The analysis of components of ERG allow to characterise the response of photoreceptor cells (hyperpolarised awave) and those of bipolar cells and Müller cells (depolarised b-wave). Visual acuity in primates can also be evaluated by considering the visual reflex (preferential looking acuity) $[5,6]$ or by measuring the visualevoked potential at the surface of the occipital cortex. These studies have shown that a diet containing vegetable oils with a very high LA/ $\alpha$-LNA ratio (greater than 200), such as sunflower, groundnut or safflower seed oils, induces a significant decrease in the electrophysiological responses, as compared to a diet with a LA/ $\alpha$-LNA ratio between 5 and 10 , obtained by adding rapeseed or soybean oil. In n-3 PUFA deficient monkeys, these alterations consisted in an increase in the delay of the ERG peak of cone and rod cells, a decrease in the a-wave amplitude [5] and an increase in the recovery time in darkness $[6,8]$. These n-3 PUFA deficiency-induced alterations have longlasting effects on the visual acuity of young primates, even after a repletion by supplementation of the diet with fish oil for several months [9]. These studies suggest that the DHA status reached during the period of perinatal development is critical for the maturation of visual function [9]. More recently, the ERG measured in newborn baboons, not deficient at birth in n-3 PUFA and fed with a formula supplemented or not in DHA for 4 weeks, has shown that the parameters of the a-wave (initial slope change, amplitude and implicit time) are all positively correlated with the retinal concentration in DHA [10].
The data obtained in deficient animals have raised the question of the neurosensorial consequences of $n-3$ fatty acid intakes in newborn humans fed with milk replacer formulas, containing corn or sunflower oils poor in - or almost devoid of $-\alpha$-LNA.

\section{BREAST VS. BOTTLE FEEDING: EFFECTS ON PUFA STATUS AND NEURAL DEVELOPMENT OF INFANTS}

\subsection{Breast milk and milk replacers have a different impact on the development of mental and visual functions}

At the beginning of the 1990s, it was shown that feeding low birth-weight premature infants with milk replacer formulas containing corn oil as the only source of lipids decreases the sensitivity of the photoreceptor cells measured by ERG [11, 12], reduces the visual-evoked potential and impairs the forced-choice preferential-looking [13]. These authors showed for the first time that feeding such a milk replacer also induces a decrease in visual acuity of 4 month old children born at term, as compared to breast-fed infants [13]. Since then, numerous studies have been conducted in infants born at term or prematurely, breast-fed or bottle-fed with formulas supplemented or not with n-3 long-chain fatty acids (reviewed in [14]). One can conclude that supplementation with DHA (or with DHA and EPA) either improves the visual acuity of the young child in a persistent or a transient way, or has no effect. It is noteworthy that no study has detected any deleterious effect of longchain PUFA supplementation on the visual acuity of the child. The differences associated with the type of feeding are less marked in the child than those shown in animal models, and in some cases are even inexistent. In normal conditions of development, newborn humans are not born with n-3 deficiency at birth, and the amplitudes 
of the structural modifications generated by bottle-feeding as compared to breast-feeding are in no way comparable to the collapse of the DHA status caused by chronic deficiencies in n-3 PUFA.

Post mortem analyses of the cortex of infants has shown that the DHA cerebral status is, at the age of 12 months, decreased by $20 \%$ with bottle feeding as compared to breast feeding [15], which represents a 3 to 4 times less important decrease than in cases of chronic deficiencies. In addition, it is impossible to standardise the intake in DHA of maternal milk since this depends on the dietary habits of the mothers; this makes breast-feeding as a nutritional and functional reference very aleatory, although it is generally considered as being the "golden standard". The determination of the functional capacities of children should also consider confounding factors, including the post-conception age, which are even more difficult to control since the distribution of children into the different feeding groups cannot always be done in a random way. A satisfying approach consists in comparing, in infants born at term, the effects of bottle feeding with formulas containing LA and $\alpha$-LNA in equilibrated proportions, and randomly supplemented or not with AA and DHA. Recent studies realised in these conditions show that the score of mental development determined at the age of 18 months is better in children receiving supplements in AA and DHA, at concentrations of $0.72 \%$ and $0.36 \%$ of total milk fatty acids, and that their visual acuity at the age of 1 year is 5/ 20ths higher as compared to children never receiving a supplement (but receiving the two precursors in an equilibrated proportion) $[16,17]$. It is to be noted that before being placed in one of the two groups (with a supplement or not), all the infants were breast-fed during their first 4 to 6 months of life, and they all had thus received during this pre-experimental period a DHA intake representing on average $0.4 \%$ of the total fatty acids in maternal milk. The authors of this study established a linear relationship between the concentration in DHA in the erythrocytes, which is itself a reflection of the quantities ingested by the child, and the visual acuity determined by the visual evoked potential method.

\subsection{PUFA supplementation of milk replacers: long-chain or precursors?}

Since the DHA status of infants fed with corn oil formulas is markedly lower than that of breast-fed infants, the readjustment of the balance between LA and $\alpha$-LNA in milk replacer formulas has appeared necessary [18]. However, raising $\alpha$-LNA in milk formula is not sufficient to reproduce the DHA blood levels of breast-fed infants. The human newborn possesses the enzymatic capacity to synthesise DHA from $\alpha$-LNA, but to a limited extent [19], and it was found to decrease with gestational age [20]. The fraction of dietary $\alpha$-LNA which is actually converted to DHA in infants is still to be determined, but it is suspected to be low. In adults, it has been estimated at less than $0.1 \%$ [21]. Finally, only milk replacer formulas supplemented with preformed DHA can ensure the same DHA status as that of breast-fed infants [22, 23].

The equilibrium between the $n-6$ and $n-3$ series in formulas can be obtained by cosupplementating with AA, so that the AA/ DHA ratio mimics that of human milk (generally comprised between 1.3 and 2.0) [24, 25]. It is well known that the PUFA levels in peripheral tissues such as the heart, intestine and liver, and particularly the levels of AA and DHA, are much more sensitive to dietary influences than the PUFA levels of nerve tissue $[26,27]$. Thus, in formula-fed newborn pigs, we have shown that supplementing the formula with DHA and EPA, but not with AA, decreased the concentration of AA by $65 \%$ in cardiac phosphatidylethanolamines (PE) as compared to sow milk-fed piglets, but only by $10 \%$ in brain cortex PE [27]. This lowering effect on the AA content was avoided by using a formula containing egg phospholipids, with $0.6 \%$ long chain $n-6$ PUFA and $0.5 \%$ long chain n-3 PUFA, allowing to reach the maximal 

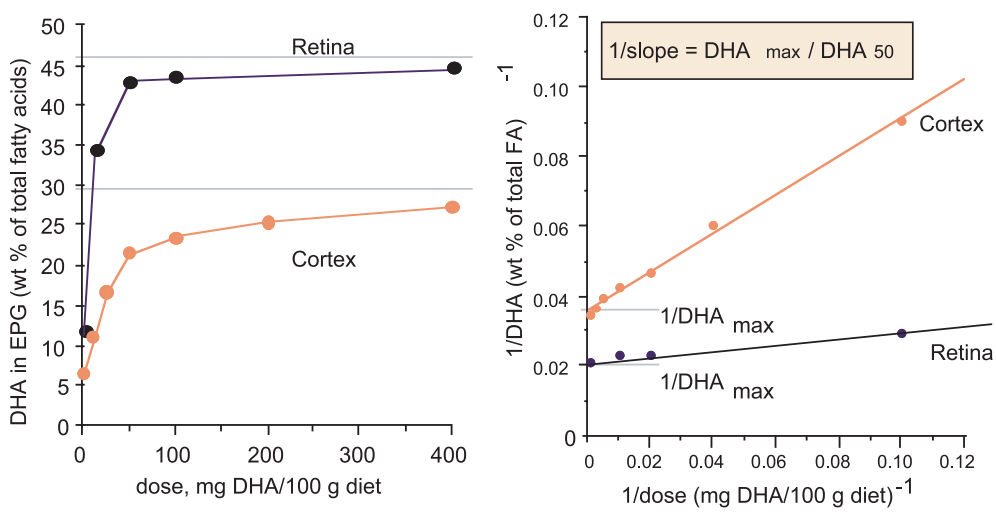

Figure 2. The plateau-value of DHA incorporation (expressed in \% of total fatty acids) in the rat brain and retina phosphatidylethanolamine (PE) fractions was computed from reciprocal plotting: the reciprocal of the DHA content (1/DHA) in PE was plotted relative to the reciprocal of the dose (1/ dose), the dose being the concentration of dietary DHA expressed in $\mathrm{mg}$ per $100 \mathrm{~g}$ of diet (from [29]). The double reciprocal plot results in the value of $1 /$ dose tending toward zero as the external DHA tends toward infinite amounts, which defines the theoretical status of DHAmax. The ordinate at the origin is thus the reciprocal of the DHAmax, and the dose giving rise to twice the value of the ordinate at the origin, i.e., one half the DHAmax, gives the DHA50. The straight line drawn through the double reciprocal data is thus described by the general equation: $(1 / \mathrm{DHA})=(1 / \mathrm{DHAmax})$ $+\mathrm{a}(1 /$ dose $)$, where $\mathrm{a}=$ slope. The reciprocal of the slope $(1 / \mathrm{a}=$ DHAmax/DHA50) is a reflection of the specific avidity of the tissue phospholipid for DHA (the lower the slope, the higher the avidity for DHA).

incorporation of DHA in the brain and retina without altering the AA status of the other tissues [27, 28]. Most of the milk replacer formulas commercialised in occidental countries, and almost all in France, are not supplemented in long-chain PUFA (AA or DHA) but only in precursors (LA and $\alpha$-LNA), which ironically makes the bottle-fed human infant the only mammal that does not receive 20 and 22 carbon PUFA during the first months of his existence.

\section{USING AN ANIMAL MODEL OF DHA DEFICIENCY AND DIETARY REPLENISHMENT TO ESTIMATE THE INFANT'S BRAIN REQUIREMENTS IN DHA}

The estimation of DHA needs in infants raises the question of the correspondence between the PUFA levels in circulating lipids (the only that are accessible to analysis) and those in nerve tissues. We have proposed a method based on the dose-response curve linking brain DHA status and dietary DHA in rats [29], and on the dose-response curve linking erythrocyte DHA level and DHA concentration of maternal milk in breastfed infants [24].

In the deficient rat model, the level of DHA in nerve tissue phospholipids from young rats born to mothers chronically deprived of n-3 fatty acids defines the lowest physiological level of DHA incorporation. When graded, increasing amounts of dietary DHA are fed throughout pre- and postnatal life to rats born to n-3 PUFA deficient mothers, the brain and retina DHA levels measured after weaning are related to DHA concentrations in the diet according to a hyperbolic dose-response curve, reaching a plateau (Fig. 2, left). The plateau values (DHAmax) were extrapolated from linear 
regression after double-reciprocal plotting (Fig. 2, right). Each phospholipid class of brain areas and retina can be characterised by its DHAmax, and by the dietary dose (DHA50) required to reach half the DHAmax. The tissue avidity for DHA is indicated by the ratio of DHAmax to DHA50: the higher the ratio, the higher the efficiency for taking up DHA from the blood to the tissue and matching its DHAmax. We found that, among rat nerve tissues, the retina had the highest DHAmax (46\% of total fatty acids in PE) but the lowest DHA50 (4 mg DHA $100 \mathrm{~g}^{-1}$ diet), and thus the highest DHAmax/DHA50 ratio (11.5). In the PE fractions from different brain areas, the DHAmax/DHA50 ratios were comprised between 1.6 and 1.9, indicating that tissue avidity for dietary DHA is 6 to 7 times lower in the brain than in the retina [29]. The method we propose to estimate the DHA requirement of the human infant is based on the assumptions that (1) the requirement is met when the DHA levels in nerve tissue reach $90 \%$ of the DHAmax, and that (2) the dose-response curves and the DHAmax/DHA50 ratios are roughly similar in young rats and in infants. According to the rat model, about 10 times the DHA50 calculated for brain PE, i.e. $180 \mathrm{mg}$ DHA $100 \mathrm{~g}^{-1}$ diet, is needed to reach $90 \%$ of the DHAmax in the brain and $97 \%$ in the retina. This dietary supply corresponds to a DHA concentration in milk of $0.8 \%$ of total fatty acids. The validity of this estimation based on animal model values is supported by a dose-response study by Gibson et al. in infants, who found that the DHA content in erythrocyte phospholipids from infants fed maternal milk containing 0.8\% DHA reaches $91 \%$ of its plateau-value (calculated from [24]). Therefore, we can estimate that the DHA status in infants fed a milk containing $0.8 \%$ DHA (corresponding to $0.4 \%$ of energy and to around $200 \mathrm{mg} \cdot \mathrm{day}^{-1}$ ) will match 90 to $97 \%$ of its maximum value in erythrocytes, brain and retina. In France, the mean DHA content in breast milk ranges from 0.3 to $0.4 \%$ of total fatty acids [25], leading theoretically to $85 \%$ of the infant erythrocyte DHAmax (calculated from [24]), and by extrapolation from the rat model, to 80 and $95 \%$ of the brain and retina DHAmax values [29].

\section{RECOMMENDED DIETARY INTAKES FOR N-3 FATTY ACIDS AND THEIR CONSUMPTION IN WESTERN COUNTRIES}

\subsection{Recommendations}

Numerous official committees of nutrition such as the Agence Française de Sécurité Sanitaire des Aliments AFSSA [30, 31] and scientific societies such as the International Society for the Study of Fatty Acids and Lipids ISSFAL $[32,33]$ have proposed recommendations for n-3 PUFA to cover human requirements throughout life (Fig. 3). The recommended values are generally expressed both as $g \cdot$ day $^{-1}$ and as \% of total energy intake. The following daily intakes are recommended for $\alpha$-LNA: $0.8-1 \%$ of energy (corresponding for adult females and males to 1.6 and $2.2 \mathrm{~g} \cdot \mathrm{day}^{-1}$ ), and for DHA: $0.05-0.1 \%$ of energy, i.e. $100-200$ and 120-240 mg.day ${ }^{-1}$ for females and males, respectively. The recommended daily intakes reach $2.2 \mathrm{~g} \alpha$-LNA and $300 \mathrm{mg}$ DHA for lactating women. For the 6-monthold infant, the $\alpha$-LNA recommended intakes range from $0.45-0.6 \%$ of energy $[31,33]$ to $1.5 \%$ (corresponding to an intake of $1 \mathrm{~g} \cdot \mathrm{day}^{-1}$ for a $650 \mathrm{Kcal}$ diet) [31]. In breast milk and infant formulas, $\alpha$-LNA amounts to 1 to $3 \%$ of total fatty acids. The DHA recommended intakes for the newborn are mainly based on the breast milk contents, which are submitted to great variations among populations $[34,35]$. The ISSFAL estimates as adequate a DHA intake of $0.15 \%$ of energy, i.e. around $80 \mathrm{mg} \cdot \mathrm{day}^{-1}$ (equivalent to $80 \mathrm{mg} \cdot \mathrm{L}^{-1}$ of milk and to $0.35 \%$ of total fatty acids). As stated above, we estimated as optimal for DHA incorporation in the developing brain and retina, a DHA intake of $0.8 \%$ of total fatty acids [29], corresponding to around $180 \mathrm{mg}$ of DHA ingested daily (Fig. 3). The value of 


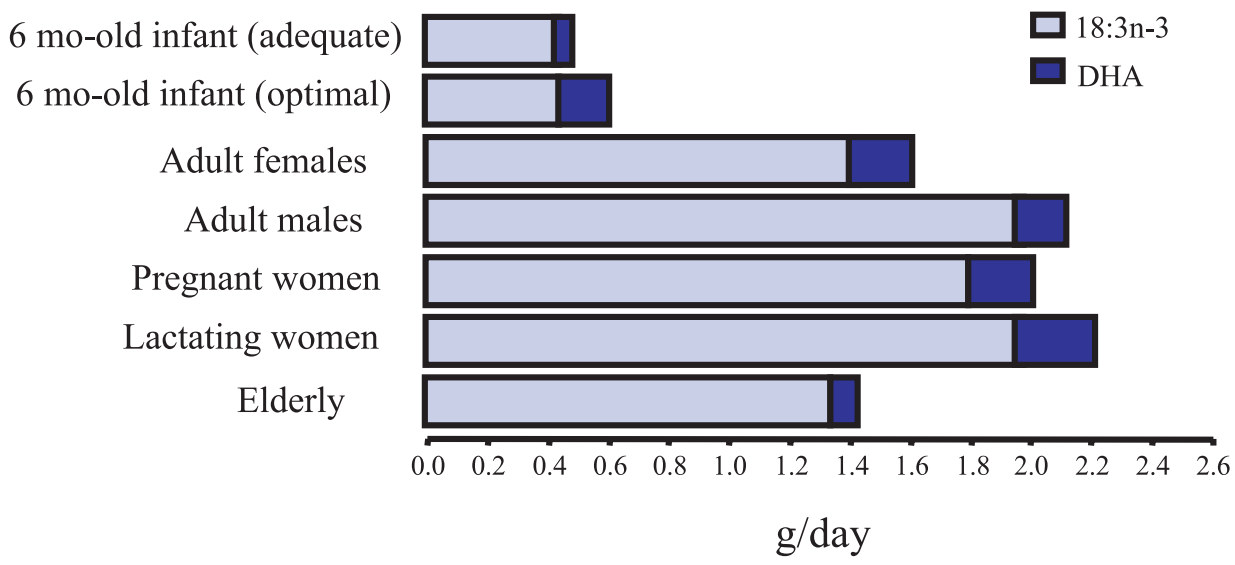

Figure 3. Recommended dietary intakes for $n-3$ fatty acids $\left(g \cdot d^{-1}\right)$ throughout life.

$0.8 \%$ of total fatty acids is in a range similar to the DHA concentrations found in the breast milk of women having fish and seafood consumption habits $[34,36]$.

\subsection{Intakes}

The estimated daily intake of n-3 PUFA in Western countries varies largely, but is often under the recommended intakes. The mean intake of $\alpha$-LNA rarely reaches the recommended intakes [37-42]. The mean DHA intakes mainly depend on fish consumption, which can differ greatly between countries [43]. In some countries, it can be below the recommended intake (90-125 vs. 200-300 mg $\cdot$ day $^{-1}$ ) [39], but it may be well over in countries with fish-eating habits [41]. In France, the mean intake of $\alpha$-LNA is one of the lowest in Europe (0.5$0.7 \mathrm{~g} \cdot \mathrm{day}^{-1}$ in women and $0.6-0.9 \mathrm{~g} \cdot \mathrm{day}^{-1}$ in men, or $0.3-0.4 \%$ of energy) $[37,42,44]$, less than half of the recommended intake. These low $\alpha$-LNA intakes, while those in LA are much higher, have to be related to the high mean value (close to 20) of the LA to $\alpha$-LNA ratio that we have found in the milk of French mothers [25, 35]. However, the mean intakes of long-chain n-3 PUFA $\left(400 \mathrm{mg} \cdot \mathrm{day}^{-1}\right.$ in women and $500 \mathrm{mg} \cdot \mathrm{day}^{-1}$ in men), and especially that of DHA
(225 mg $\cdot$ day $^{-1}$ in women and $270 \mathrm{mg} \cdot \mathrm{day}^{-1}$ in men), appear to meet the recommendations, although with very large individual variations [42]. Therefore, it would be useful to increase the intake of $\alpha$-LNA by consuming $\alpha$-LNA-rich vegetable oils, such as rapeseed or soybean oils, and to encourage the consumption of fatty fish in persons who never eat fish, or who eat fish only rarely.

\section{N-3 PUFA AND \\ NEUROPSYCHIATRIC DISEASES}

\subsection{Clinical data}

Essential PUFA can affect brain functions beyond the critical period of perinatal development. Alterations of n-6 and n-3 status have been associated with psychiatric pathologies in children and adults. Decreases in the blood levels of n-3 and/or n-6 PUFA have been observed in patients with depression [45-50], bipolar disorder [51, 52], schizophrenia [53-57], child hyperactivity [58] and autism [59]. Whether these alterations of the essential fatty acid contents of blood lipids are implicated in the etiology of the diseases, and whether they are causes or only side consequences of the 
pathologies are still matters of debate. In the case of schizophrenia, decreased levels of both n-3 PUFA (EPA, n-3 DPA, DHA) and AA in blood lipids have been repeatedly observed [53-57]. These alterations are correlated to the intensity of psychotic symptoms of nontreated patients [57] and tend to be normalised by a neuroleptic treatment $[56,57]$, which suggests that the decrease of blood PUFA levels is tightly involved in the pathophysiology of the disease. There is to-date little argument, however, that a lower PUFA status due to dietary deficiencies could be by itself an independent cause or even a risk factor for this disease with a strong genetic background. At variance, patients with depression showed decreased levels of one or several n-3 PUFA ( $\alpha$-LNA, EPA, n-3 DPA, DHA) in blood lipids (as compared to non-depressed controls), but not of n-6 PUFA [45-49]. Some studies have shown a negative correlation between the n-3 PUFA levels or the EPA/AA ratio in erythrocytes and the depression score of the patients $[45,48]$. In one study [48], the levels of $\alpha$-LNA, EPA, DPA and DHA in erythrocytes were correlated positively with their respective dietary intakes, which suggests that their lower levels found in depressed patients could be a consequence of a dietary deficiency. A study on post-partum depression found that women who have developed postpartum depression had less DHA in plasma lipids at delivery than women who did not, which suggests a causal relation between a lower n-3 PUFAs status at delivery and the ulterior onset of depression [50].

\subsection{Epidemiological studies}

The possible relations between fish or $n-3$ PUFA intakes or PUFA status and depression or other mood disorders have been further investigated in epidemiological population studies. Several international comparison studies have searched the existence of an association between mean fish consumption and the prevalence of affective disor- ders in different countries around the world. A strong decreasing relation was found between the prevalence of major depression [60], postpartum depression [61] and bipolar spectrum disorders [62] and the apparent mean fish and seafood consumption calculated from FAO statistics. In the case of postpartum depression, both a greater fish and seafood consumption and a higher DHA content of mother's milk predicted a lower postpartum depression prevalence [61]. No such relation was observed with the prevalence of schizophrenia, suggesting that it would be specific to affective disorders [62]. In these ecological studies, however, the relations found can be in part due to many possible confounding factors (genetic, cultural, environmental), especially since the countries with the lowest rates of mood disorders are mainly Asian countries (Taiwan, Korea, Japan, Singapore, Hong-Kong, Malaysia), but there are also other countries such as Iceland or Chile.

Other types of epidemiological studies (cross-sectional, case-control, nested casecontrol and cohorts) dealing with fish or n-3 PUFA intake and depression or depression-related endpoints are summarised in Table I. One large cohort study in Japan found a negative association between fish consumption at the baseline and suicide rate during follow-up [63]. A case-control study in China found a strong association between suicide attempt and low EPA and DHA levels in red blood cells [64]. Five cross-sectional studies in Finland, New Zealand and Japan found a significant negative association of depression or depressive symptoms with fish consumption [65-68], or with the intake of $\alpha$-LNA [69]. When men and women were analysed separately, this association was only seen in women $[65,68]$. Two small cross-sectional studies in population samples from Crete and a nested case-control study in the Netherlands found lower levels of $\alpha$-LNA or of DHA in the blood or adipose tissue of depressed subjects than of nondepressed subjects [70-72]. Finally, only one large cohort of men smokers in Finland did not report any inverse association of fish 
Table I. Fish and polyunsaturated fatty acid intake and depression: epidemiologic observational studies.

\begin{tabular}{|c|c|c|c|c|c|c|}
\hline Country, period & Study type & $\begin{array}{l}\text { Sample size: } \\
\text { cases/controls or cases } \\
\text { (cohort) and age (yr) }\end{array}$ & $\begin{array}{l}\text { Fish or n-3 PUFA intake } \\
\text { (contrast for OR or RR), or } \\
\text { blood or tissue biomarker }\end{array}$ & Method/endpoints & $\begin{array}{l}\text { Odds ratio (OR) or relative risk (RR) } \\
\text { (95\% confidence interval) or main result, } \\
\text { and } P \text { for trend or difference }\end{array}$ & Reference \\
\hline $\begin{array}{l}\text { Japan, 1965-1982 } \\
\text { (follow-up } \\
\text { period) }\end{array}$ & Cohort & $\begin{array}{l}870(265118) \\
\text { men and women } \\
\geq 40 \text { at inclusion }\end{array}$ & $\begin{array}{l}\text { daily vs. non-daily } \\
\text { fish intake }\end{array}$ & death register/suicide & $\begin{array}{l}0.81(0.72-0.91) \\
P \text { not determined }\end{array}$ & [63] \\
\hline China, 2002 & Case-control & $\begin{array}{l}100 / 100 \\
\text { men and women } \\
\text { (all ages) }\end{array}$ & $\begin{array}{l}\text { EPA and DHA \% } \\
\text { in red cell PL } \\
\text { 4th vs. 1st quartile }\end{array}$ & $\begin{array}{l}\text { hospital admitted patients: } \\
\text { suicide attempt cases vs. accident } \\
\text { trauma controls }\end{array}$ & $\begin{array}{l}\text { EPA: } 012(0.04-0.36) P=0.0001 \\
\text { DHA: } 0.21(0.07-0.60) P=0.002\end{array}$ & [64] \\
\hline Finland, 1992 & Cross-sectional & $\begin{array}{l}896(3403) \\
\text { men and women } \\
25-64\end{array}$ & $\begin{array}{l}\geq 1 \text { fish meal.week }{ }^{-1} \\
\text { vs. less often }\end{array}$ & $\begin{array}{l}\text { self-reported depressive } \\
\text { symptoms (BDI) }\end{array}$ & $\begin{array}{c}0.76(0.64-0.91) \\
0.71(0.56-0.90) \text { in women }(P<0.01), \\
\text { not significant in men }\end{array}$ & [65] \\
\hline Finland, 1999 & Cross-sectional & $\begin{array}{l}\text { not reported (1 767) } \\
\text { men and women, } \\
25-64\end{array}$ & $\begin{array}{l}\geq 2 \text { fish meals } \cdot \text { week }^{-1} \\
\text { vs. less often }\end{array}$ & $\begin{array}{l}\text { self-reported depressive } \\
\text { symptoms (BDI) }\end{array}$ & $\begin{array}{c}0.63(0.43-0.94) \\
P=0.02\end{array}$ & [66] \\
\hline $\begin{array}{l}\text { New Zealand, } \\
1996-1997\end{array}$ & Cross-sectional & $\begin{array}{c}(4644) \\
\text { men and women, } \geq 15\end{array}$ & $\begin{array}{l}\text { any fish intake } \\
\text { vs. no fish intake }\end{array}$ & self-reported mental health (SF-36) & $\begin{array}{l}\text { higher mental health score } \\
\text { in fish consumers } P<0.01\end{array}$ & [67] \\
\hline $\begin{array}{l}\text { Crete, } \\
1999\end{array}$ & Cross-sectional & $\begin{array}{c}22(143) \\
\text { men and women, mean } 39\end{array}$ & $\begin{array}{l}\% \text { fatty acids in } \\
\text { adipose tissue }\end{array}$ & $\begin{array}{l}\text { self-reported depressive } \\
\text { symptoms (Zung) }\end{array}$ & $\begin{array}{l}\text { less DHA in mildly depressed subjects, } \\
\qquad P<0.01\end{array}$ & [70] \\
\hline Crete, 2000 & Cross-sectional & $\begin{array}{c}24(67) \\
\text { men, mean } 85\end{array}$ & $\begin{array}{l}\% \text { fatty acids in } \\
\text { adipose tissue }\end{array}$ & $\begin{array}{l}\text { depressive symptoms } \\
\text { (GDS-15) }\end{array}$ & $\begin{array}{c}\text { less } \alpha \text {-LNA in depressed } \\
\text { subjects } P<0.02\end{array}$ & [71] \\
\hline $\begin{array}{l}\text { Netherlands } \\
1997-1999\end{array}$ & $\begin{array}{c}\text { Nested } \\
\text { case-control }\end{array}$ & $\begin{array}{c}264 / 461 \\
\text { among } 3884 \\
\text { men and women, } \geq 60\end{array}$ & $\begin{array}{c}\% \text { fatty acids in } \\
\text { plasma phospholipids }\end{array}$ & psychiatric interview & $\begin{array}{c}\text { less DHA and more } \\
\text { AA in depressed subjects } \\
P=0.05\end{array}$ & [72] \\
\hline Japan & Cross-sectional & $\begin{array}{c}436(771) \\
\text { men and women lung } \\
\text { cancer patients, mean } 64\end{array}$ & $\begin{array}{l}\alpha \text {-LNA, EPA and DHA } \\
\text { intakes } \\
\text { (4th vs. 1st quartile) }\end{array}$ & $\begin{array}{l}\text { depression } \\
\text { (HADS-D) }\end{array}$ & $\begin{array}{c}\alpha \text {-LNA: } 0.50(0.31-0.71) \\
P=0.004 \\
\text { no association with EPA or DHA }\end{array}$ & [69] \\
\hline $\begin{array}{l}\text { Finland, 1985-1994 } \\
\text { (follow-up period) }\end{array}$ & $\begin{array}{c}\text { Cohort } \\
\text { (ATBC study) }\end{array}$ & $\begin{array}{l}8,612(27111) \\
\text { male smokers } \\
50-69\end{array}$ & $\begin{array}{l}\text { fish, fish and vegetable } \\
\text { n-3 PUFA intakes } \\
\text { (3rd vs. 1st tertile) }\end{array}$ & $\begin{array}{l}\text { self-reported depressed mood } \\
\text { during follow-up }\end{array}$ & $\begin{array}{c}\text { fish intake: } 1.06(1.00-1.12) \\
P=0.04 ; \text { no association with } \\
\alpha \text {-LNA, EPA or DHA }\end{array}$ & [73] \\
\hline Finland, 1997 & $\begin{array}{l}\text { Cross-sectional } \\
\text { (in a cohort) }\end{array}$ & $\begin{array}{l}107 \text { to } 483(8463) \\
\text { men and women, } \\
\text { mean } 31\end{array}$ & $\begin{array}{l}\geq 1 \text { fish meal } / \text { week } \\
\text { vs. less often }\end{array}$ & $\begin{array}{l}\text { self-reported depression } \\
\text { (HSCL-25) and doctor-diagnosed } \\
\text { lifetime depression }\end{array}$ & $\begin{array}{c}\text { in women: lifetime depression } 0.83 \\
(0.62-1.11) \text {; current depression } 0.71 \\
(0.55-0.91) \text {; both } 0.42(0.24-0.71) \\
\text { no association in men }\end{array}$ & [68] \\
\hline
\end{tabular}


or n-3 PUFA intakes with depression [73]. On the whole, most studies have found a negative association of depression or depressive symptoms with fish or n-3 PUFA intake, or with n-3 PUFA levels in blood or adipose tissue. The relation was seen among women, not (or not significantly) among men. Thus, there is a strong suspicion from epidemiological studies that a low fish or n-3 PUFA intake can increase depression or suicide risk, especially in women, but studies with a prospective design are still needed to prove it.

\subsection{Intervention studies: specific effects for EPA and DHA?}

Randomised, double-blind, placebocontrolled intervention studies have been undertaken to test the effect of n-3 PUFA (fish oil, EPA or DHA) in psychiatric patients with diverse diagnoses. Those of these studies which deal with mood disorders are summarised in Table II. EPA at the dose of 1 or $2 \mathrm{~g} \cdot$ day $^{-1}$ has shown efficacy in reducing symptoms of treated depressive patients $[74,75]$, but not, curiously, at a higher dose [75]. A high dose of EPA $\left(6 \mathrm{~g} \cdot \mathrm{day}^{-1}\right)$ did not improve bipolar patients [76]. However fish oil providing 4-6 g EPA and 2-3 g DHA. day ${ }^{-1}$ appeared to improve both depressive and bipolar patients [77, 78], including bipolar patients receiving no other treatment [77]. In the latter trial on bipolar patients, the improvement due to fish oil treatment consisted in a lower rate of depressive relapses [77]. EPA at $1 \mathrm{~g} \cdot \mathrm{day}^{-1}$ was efficient in reducing both aggression and depression symptoms of women with untreated borderline personality disorder [79]. In contrast, DHA showed no effect on depression in the two studies where it was tested as the only treatment $[80,81]$. In particular, DHA at a dose sufficient to prevent its depletion during pregnancy and lactation $\left(200 \mathrm{mg} \cdot \mathrm{day}^{-1}\right)$ has no effect on postpartum depression rate when given to breast-feeding women after delivery [81], which suggests that either higher doses are required, or that supplementing during preg- nancy is necessary, or that DHA by itself is not active in preventing postpartum depression.

EPA or DHA as the only or adjunctive treatment have been tested in psychiatric disorders other than mood disorders. EPA as adjunctive treatment helps to improve schizophrenic patients when given at the dose of 2-3 g.day ${ }^{-1}$ [82-84], but not, again, at higher doses [83], whereas DHA showed no effect [82]. One trial on children with learning problems and attention-deficit hyperactivity disorder (ADHD) symptoms has shown a significant improvement in subjects receiving a mixture of n-6 and n-3 PUFA as the only treatment [85]. In a series of open cases, young girls with anorexia nervosa improved or recovered when treated with EPA $\left(1 \mathrm{~g} \cdot\right.$ day $\left.^{-1}\right)$ in addition to a standard treatment [86].

On the whole, EPA at doses varying from 1 to $3 \mathrm{~g} \cdot \mathrm{day}^{-1}$, or fish oil at higher doses appear to improve psychiatric patients with astonishingly diverse diagnoses. DHA showed no effect in the few trials where it was tested. In schizophrenic patients, improvement due to EPA treatment was surprisingly correlated with the rise of red blood cell AA level [83, 87]. The fact that high doses $\left(\geq 4 \mathrm{~g} \cdot \mathrm{day}^{-1}\right)$ of pure EPA are not efficient (or less than lower doses) in schizophrenic, depressive and bipolar patients, might be related to a decrease (or a lack of restoration) of the membrane levels of AA [84]. Other trials are warranted to determine the efficacy of n-3 PUFA in psychiatric patients. Owing to the high prevalence of depression in Western countries, an increasing interest is borne to the potential preventive and therapeutic role of n-3 PUFA in depression, in particular: (1) in cases where a standard antidepressant treatment is not indicated or not desired (depression of low or moderate intensity, depression during pregnancy); (2) as a maintenance or preventive treatment in at-risk subjects (patients with previous depressive episodes, pregnant women, dysthymic subjects, etc). 
Table II. n-3 polyunsaturated fatty acids and mood or mood-related disorders: randomised, placebo-controlled interventional studies. Borderline personality disorder (BPD) is generally not classified in mood disorders; we include here one trial on BPD, since it involves the evaluation of depressive symptoms.

\begin{tabular}{|c|c|c|c|c|c|}
\hline $\begin{array}{l}\text { Country, sample } \\
\text { size and duration }\end{array}$ & Diagnosis & Intervention & Endpoints & Results & Reference \\
\hline $\begin{array}{l}\text { Israel } \\
3 \text { men and } 17 \text { women } \\
4 \text { weeks }\end{array}$ & $\begin{array}{l}\text { Past episodes of depression and } \\
\text { current major depression, } \\
\text { treated but resistant }\end{array}$ & $\begin{array}{l}\text { Adjunctive ethyl-EPA } \\
2 \mathrm{~g} \cdot \text { day }^{-1} \text {, or placebo }\end{array}$ & $\begin{array}{l}\text { Depression score (Hamilton } \\
\text { Depression Rating Scale) at } \\
\text { baseline and after 1-4 weeks }\end{array}$ & $\begin{array}{l}\text { Depression score lower in EPA group than in } \\
\text { placebo after } 2 \text { weeks; } 50 \% \text { decrease after } 4 \text { weeks } \\
\text { on EPA, whereas no decrease in placebo group }\end{array}$ & [74] \\
\hline $\begin{array}{l}\text { UK } \\
11 \text { men and } 59 \text { women } \\
12 \text { weeks }\end{array}$ & $\begin{array}{l}\text { Persistent major depression } \\
\text { despite ongoing treatment }\end{array}$ & $\begin{array}{l}\text { Adjunctive ethyl-EPA } \\
1,2 \text { or } 4 \mathrm{~g} \cdot \text { day }^{-1} \text {, or placebo }\end{array}$ & $\begin{array}{l}\text { Depression scores (HDRS, } \\
\text { MADRS, BDI) at baseline } \\
\text { and after } 4,8 \text { and } 12 \text { weeks }\end{array}$ & $\begin{array}{c}\text { Depression scores lower in the } 1 \mathrm{~g} \mathrm{EPA} \cdot \mathrm{day}^{-1} \text { group } \\
\text { than in the placebo group at all time points; no or } \\
\text { marginal effect of EPA at the doses of } 2 \cdot \mathrm{day}^{-1} \text { and } \\
4 \mathrm{~g} \cdot \mathrm{day}^{-1}\end{array}$ & [75] \\
\hline $\begin{array}{l}\text { Taiwan } \\
4 \text { men and } 18 \text { women } \\
8 \text { weeks }\end{array}$ & $\begin{array}{l}\text { Major depression, ongoing } \\
\text { treatment }\end{array}$ & $\begin{array}{l}\text { Adjunctive fish oil, } \\
4.4 \mathrm{~g} \mathrm{EPA}^{2} 2.2 \mathrm{~g} \\
\text { DHA } \text { day }^{-1} \text {, or placebo }\end{array}$ & $\begin{array}{l}\text { Depression score (HDRS) at } \\
\text { baseline and after } 8 \text { weeks }\end{array}$ & $\begin{array}{l}\text { Depression score lower in the group receiving fish oil } \\
\text { than in the placebo group after } 8 \text { weeks }\end{array}$ & [78] \\
\hline $\begin{array}{l}\text { USA } \\
35 \text { men and women } \\
6 \text { weeks }\end{array}$ & $\begin{array}{l}\text { Major depression, } \\
\text { no ongoing treatment }\end{array}$ & $\begin{array}{l}\text { DHA } 2 \mathrm{~g} \cdot \text { day }^{-1} \\
\text { or placebo }\end{array}$ & $\begin{array}{l}\text { Depression scores (HDRS, } \\
\text { MADRS) }\end{array}$ & No effect of DHA on depression scores & [80] \\
\hline $\begin{array}{l}\text { USA } \\
89 \text { women at delivery } \\
4 \text { months }\end{array}$ & $\begin{array}{l}\text { Women at delivery, planning to } \\
\text { breast-feed } \\
\text { for at least } 4 \text { months }\end{array}$ & $\begin{array}{l}\text { DHA (as algae oil) } \\
200 \mathrm{mg}^{-1 a y^{-1}} \\
\text { or placebo }\end{array}$ & $\begin{array}{l}\text { Self-rated depression score } \\
\text { (BDI) at baseline, } 3 \text { weeks, } \\
2 \text { and } 4 \text { months ; postpartum } \\
\text { depression score (EPDS) } \\
\text { at } 18 \text { months }\end{array}$ & $\begin{array}{l}\text { No effect of DHA on depression scores } \\
\text { or depression rate at any time point }\end{array}$ & [81] \\
\hline $\begin{array}{l}\text { USA } \\
10 \text { men and } \\
20 \text { women } \\
4 \text { months }\end{array}$ & $\begin{array}{l}\text { Bipolar disorder I or II, ongoing } \\
\text { mood-stabilizing treatment }(22) \\
\quad \text { or no treatment }(8)\end{array}$ & $\begin{array}{l}\text { Fish oil, } 6.2 \mathrm{~g} \mathrm{EPA}+ \\
3.4 \mathrm{~g} \mathrm{DHA}^{- \text {day }^{-1}, \text { or }} \\
\text { placebo, adjunctive } \\
\quad \text { or alone }\end{array}$ & $\begin{array}{l}\text { Duration of time to exit the } \\
\text { trial because of a depressive } \\
\text { relapse requiring a new } \\
\text { treatment }\end{array}$ & $\begin{array}{l}\text { Greater mean duration of time remaining in the study } \\
\text { and less depressive relapses in the fish oil-treated } \\
\text { group, including among the patients receiving no } \\
\text { other treatment }\end{array}$ & [77] \\
\hline $\begin{array}{l}\text { USA } \\
121 \text { men and women } \\
4 \text { months }\end{array}$ & $\begin{array}{c}\text { Bipolar disorder: current acute } \\
\text { depression (59) or rapid cycling } \\
\text { (62) }\end{array}$ & $\begin{array}{l}\text { Adjunctive EPA } 6 \mathrm{~g} \cdot \mathrm{day}^{-1} \text {, } \\
\text { or placebo }\end{array}$ & Depression score (?) & No clinical response of EPA & [76] \\
\hline $\begin{array}{l}\text { USA } \\
20 \text { women } \\
8 \text { weeks }\end{array}$ & $\begin{array}{l}\text { Borderline personality } \\
\text { disorder, not treated }\end{array}$ & $\begin{array}{l}\text { Ethyl-EPA } 1 \mathrm{~g} \cdot \text { day }^{-1} \\
\text { or placebo }\end{array}$ & $\begin{array}{l}\text { Aggression score (MOAS) } \\
\text { and depression score } \\
\text { (MADRS) at baseline and } \\
\text { after } 2-8 \text { weeks }\end{array}$ & $\begin{array}{c}\text { Past episodes of depression and current major } \\
\text { depression, treated but resistant } \\
\text { Better improvement of patients receiving } \\
\text { EPA than those receiving placebo on both agression } \\
\text { and depression scores }\end{array}$ & [79] \\
\hline
\end{tabular}




\section{PUFA STATUS AND NEURO- DEGENERATIVE DISEASES}

\subsection{PUFA status in Alzheimer disease}

Modifications of the PUFA status have also been associated with neurodegenerative diseases, in particular Alzheimer disease. Alzheimer disease is the most frequent neurodegenerative dementia occurring in elderly people. Contrary to vascular dementias, which are secondary to vascular events, the etiology of Alzheimer disease appears to be idiopathic, and only concerns brain cells. Case-control studies have shown that patients affected with Alzheimer disease present 30 to $50 \%$ lower concentrations of EPA and DHA in their erythrocyte or serum lipids than normal subjects of the same age $[88,89]$. In both a cross-sectional study and a prospective study in population samples of mean-old age (45-75 years), a higher intake of marine n-3 PUFA or a higher percentage of EPA and DHA in erythrocytes were associated with a lower risk of cognitive decline [90, 91]. Several prospective studies have examined if a relationship exists between baseline consumption of sea products rich in n-3 PUFA and the incidence of Alzheimer disease. People eating fish or seafood once a week or more have a risk of developing Alzheimer disease in the following years 30 to $70 \%$ lower than people eating seafood only rarely or never [9294]. In one of these studies, the detailed analysis of the n-3 PUFA intakes showed that a decreased risk was strongly associated with the intake of DHA, but not with the intakes of EPA or $\alpha$-LNA [93]. A 70\% decreased risk was found in persons with a daily intake of $100 \mathrm{mg}$ DHA (highest quintile), as compared to those with a daily intake of $30 \mathrm{mg}$ DHA (lowest quintile) [93]. This result could suggest that, on the contrary to depression, dietary DHA, rather than EPA, is involved in neuroprotective processes which prevent or delay the development of Alzheimer disease, but more evidence, in particular from intervention studies, is needed to support this hypothesis. In fact, in observational studies, it is generally difficult to separately analyse the effects of dietary EPA and DHA, since both of them are always strongly correlated with fish and seafood intake. In addition to the association observed with Alzheimer disease, isolated, small uncontrolled open clinical trials suggest a possible efficacy of n-3 PUFA in other neurological diseases: multiple sclerosis [95], epilepsy [96], and Huntington disease [97].

\subsection{Trial of DHA treatment in rat studies}

Since the protecting effect of DHA seems to be associated with well-installed food habits, it is possible that the mechanisms implicated concern the concentration of this fatty acid in brain tissue membranes. This hypothesis seems to be supported by the results of a Japanese study using an animal model for the infusion of the amyloid $\mathrm{A} \beta$ peptide by intracerebral microdialysis, reproducing the neurofibrillar degenerescence of Alzheimer disease [98]. Infused rats presented lipoperoxidation products and neuronal apoptosis signs, and their learning capacities strongly decreased. These effects were cancelled if the rats had ingested $100 \mathrm{mg}$ DHA daily during 12 weeks before the infusion of the $A \beta$ peptide, which increased the concentration of DHA in the brain by $30 \%$ as compared to rats not receiving any supplement. In the third session of the test implicating the memory function, the performances of the rats pretreated with DHA and infused with the amyloid peptide were higher than those of placebo rats and closer to those of rats pretreated with DHA and not being infused. The authors suggested that DHA has an antioxidant neuroprotecting effect on the apoptotic process induced by free radicals and lipoperoxidation products.

\section{MECHANISMS OF ACTION OF N-3 PUFA IN THE BRAIN AND RETINA: FOUR HYPOTHESES}

The different hypotheses emitted to explain the mechanisms of action of PUFA 
illustrates the wide diversity of the regulated functions by these components. Although the different pathways may be strongly interconnected at all the molecular, cellular and physiological levels, four hypotheses will be successively and separately presented within the framework of this paper.

\subsection{PUFA are precursors of active mediators}

\subsubsection{Synthesis of eicosanoids}

This pathway of PUFA action on nerve cells starts with their release from the internal sn- 2 position of membrane phospholipids under the action of a hormone- or a calcium-dependent phospholipase A2 (PLA2). PUFA with 20 carbon atoms (AA, EPA, and dihomo-gamma-linolenic acid or DGLA, 20:3n-6) are then converted in oxygenated products, eicosanoids (Fig. 4). The reactions are catalysed by 15-lipoxygenase (15-LOX), 5-lipoxygenase (5-LOX) or cyclo-oxygenases (COX1 and COX2). The 15-LOX and 5-LOX pathways lead to the formation of lipoxins and leukotrienes involved in immune and inflammatory reactions, whereas COX pathways produce endoperoxides, which are notably active in the constriction of blood vessels and in platelet aggregation. Prostaglandins, prostacyclins and thromboxanes of the 1,2, and 3 series are produced by the COX pathway from respectively DGLA, AA and EPA. The 5-LOX pathway leads to leucotrienes of the series 4 from AA and of the series 5 from EPA. Since the fatty acid substrates are competing for the same enzymes, the biosynthesis of endoperoxides of the series 1 and 3 counteracts that of the series 2 , and the biosynthesis of leucotrienes of the series 5 counteracts that of the series 4 . The dietary equilibrium between the n- 6 and n-3 fatty acids thus determines the balance in the synthesis of active mediators whose properties are generally opposed. AA generates proagregant and vasoconstrictor (series 2 endoperoxides) and proinflammatory (series 4 leucotrienes) mediators, whereas the mediators issued from EPA have antiagregating and vasodilating properties (endoperoxides of the series 3 ), and non-inflammatory properties (series 5 leucotrienes).

\subsubsection{Eicosanoids and the regulator role of astrocytes}

The AA-derived eicosanoids probably have an action in the brain. By binding on astrocyte membrane receptors, the series 2 prostaglandins, produced in response to an influx of calcium ions, may be involved in the regulation of the glutamate release in the synaptic cleft (for a review see [99]). The released glutamate modulates neuronal excitability and synaptic transmission at the presynaptic level. On the contrary, glutamate uptake by astrocytes (Fig. 5), avoids its potentially neurotoxic accumulation in the synaptic cleft. A defect in the astrocytic uptake of glutamate may be the cause of neuronal damages acquired during traumatisms (ischemia, lesions) and could be associated to several neurodegenerative pathologies. Moreover, the excessive release of AA could alter glutamate transporters and contribute to the extracellular accumulation of glutamate. The effects of oxidative stress on glutamate transport is possibly mediated by a product of PUFA peroxidation, 4-hydroxynonenal, which may interact with the GLT-1 astrocyte transporter (EAAT2) and induce its inactivation [100]. Under the action of different stimuli, especially in response to proinflammatory cytokines [101], astrocytes in the synaptic cleft also release a sPLA2 which releases AA from the sn- 2 position of membrane phospholipids. Compared to AA, EPA and DHA are less good substrates for LOX and COX, and they modulate the nature and amounts of the oxygenated derivatives [102-105]. Increasing the dietary intake of n-3 PUFA could thus slow down the inflammatory cycle maintained by the action of cytokines on astrocytes, i.e. the secretion of SPLA2, a large release of AA and production of PGE2 in the extracellular space, inducing in return the synthesis of inflammatory interleukins by astrocytes [99]. 

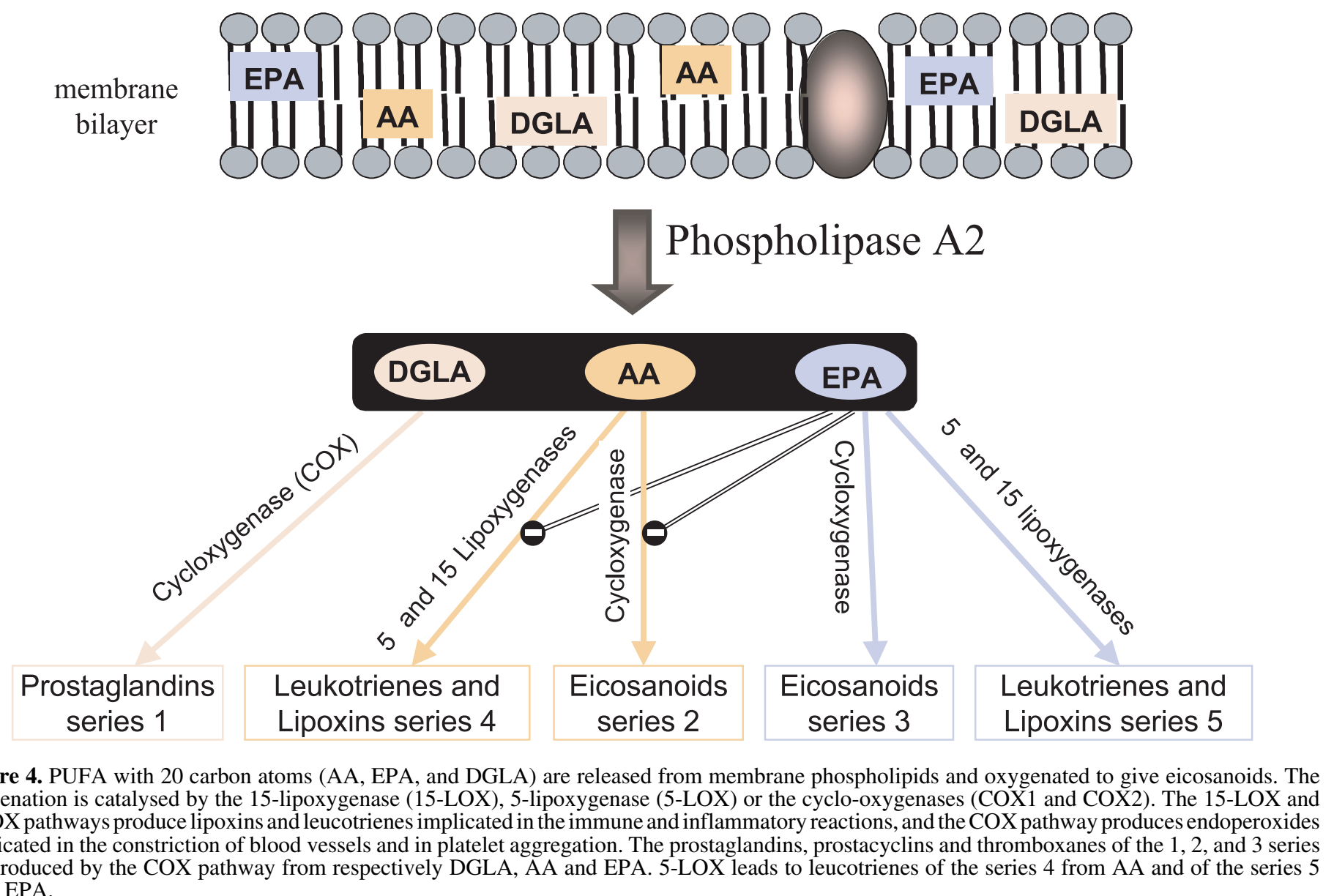

Figure 4. PUFA with 20 carbon atoms (AA, EPA, and DGLA) are released from membrane phospholipids and oxygenated to give eicosanoids. The oxygenation is catalysed by the 15-lipoxygenase (15-LOX), 5-lipoxygenase (5-LOX) or the cyclo-oxygenases (COX1 and COX2). The 15-LOX and 5-LOX pathways produce lipoxins and leucotrienes implicated in the immune and inflammatory reactions, and the COX pathway produces endoperoxides implicated in the constriction of blood vessels and in platelet aggregation. The prostaglandins, prostacyclins and thromboxanes of the 1,2 , and 3 series are produced by the COX pathway from respectively DGLA, AA and EPA. 5-LOX leads to leucotrienes of the series 4 from AA and of the series 5 from EPA. 


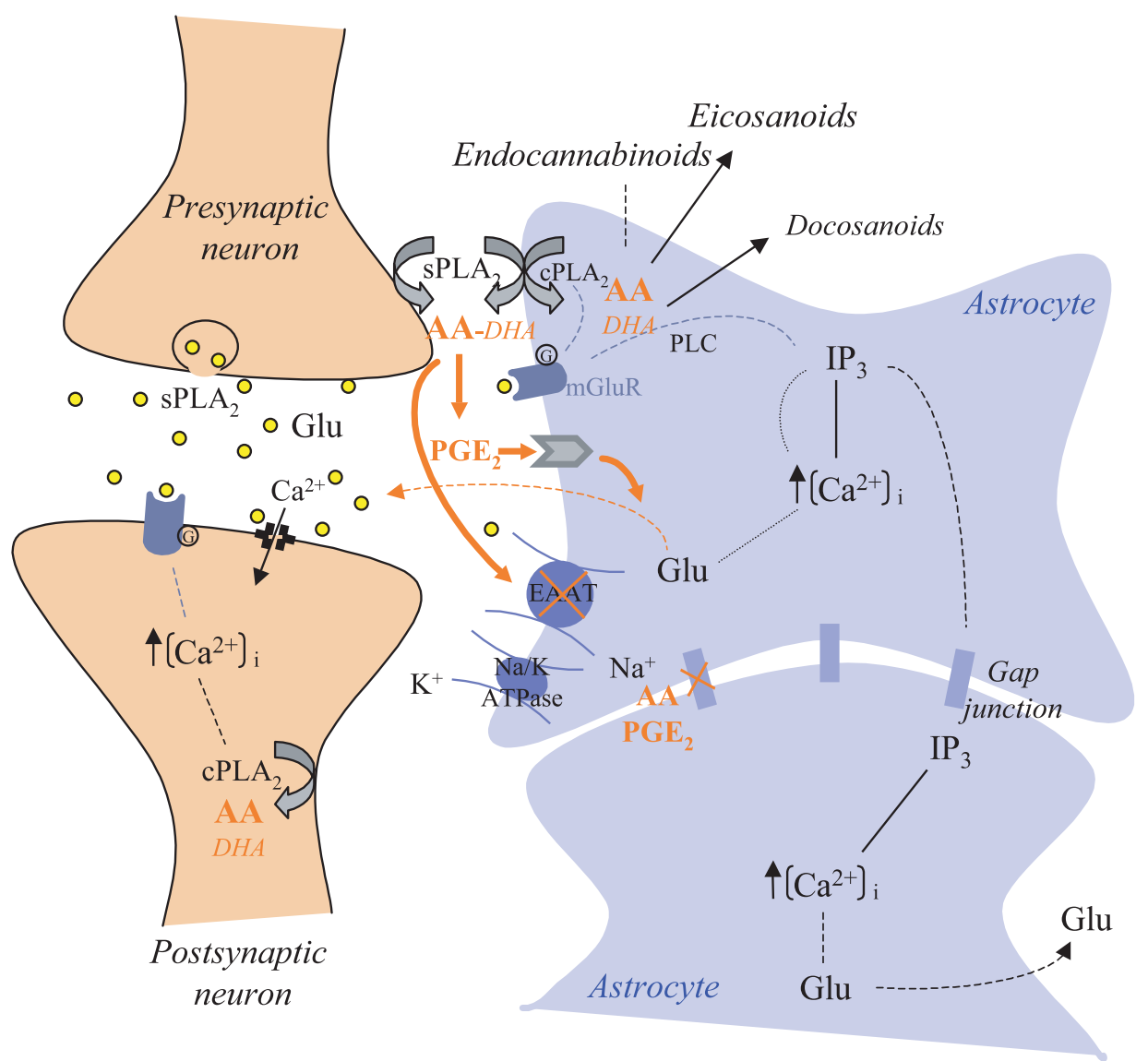

Figure 5. Implication of PUFA in the synaptic regulation by astrocytes: the release of glutamate (Glu) during neuronal activation induces a calcium influx in the postsynaptic neurons and an activation of neuronal and astrocytic glutamate receptors. The activation of metabotropic receptors (mGluR) results in an increase of intracellular calcium concentration through the $\mathrm{IP}_{3}$ pathway [phospholipase $\mathrm{C}$ (PLC) activation, $\mathrm{IP}_{3}$ increase, calcium release of intracellular pools]. Calcium-mediated activation of the cytoplasmic phospholipase $\mathrm{A}_{2}\left(\mathrm{CPLA}_{2}\right)$ produces the release of AA and DHA from membrane phospholipids. The $\mathrm{CPLA}_{2}$ may be directly activated through G-protein-linked mGluR. A secretory PLA ${ }_{2}\left(\mathrm{sLA}_{2}\right)$, may be released from the presynaptic terminal. Lipid signalling can modulate neuronal function and survival in several ways : (1) Free AA regulates the extracellular concentration of glutamate by inhibiting the glutamate uptake by the astrocyte transporter (EAAT), and by activating its release in a $\mathrm{Ca}^{2+}$-dependent mechanism via the stimulation of the astrocyte receptors for $\mathrm{PGE}_{2}$ (prostaglandins $\mathrm{E}_{2}$ ). (2) Free AA and DHA may enter the enzymatic oxygenation pathways, producing the respective eicosanoids and docosanoids which can also regulate the synaptic transmission. (3) AA and $\mathrm{PGE}_{2}$ can regulate through the $\mathrm{IP}_{3}$-mediated propagation of $\mathrm{Ca}^{2+}$ waves throughout the glial cells through inhibition of gap junctions.

We recently showed that the concentrations in DHA and AA in the phospholipid membranes of cultured astrocytes vary as a function of the concentration of the fatty acids in this medium, and notably that the concentration of $\mathrm{AA}$ is inversely related to the concentration of DHA [106]. In addition, we observed that supplemental DHA 
has an effect on the morphology of astrocytes from primary culture, which exhibit a stellar shape different from that induced by AA (Denis et al., unpublished results). In the brain, the reversible process of astrocytic stellation allows the emission and the retraction of the astrocytic processes around the synapses, thus regulating the neuronal energy flux and the ion and neurotransmitter homeostasis in the synaptic cleft (review in [107]). The hypothesis can be made that the respective proportions of DHA and AA in membranes may have an impact on the morphological plasticity and on the different astrocyte functions involved in the regulation of synaptic transmission.

\subsubsection{New mediators, the docosanoids}

The nerve membranes contain much more AA than EPA, which makes the local synthesis of eicosanoids from cerebral EPA quite questionable. However, these membranes contain almost as much DHA as AA, or even more in the case of the retina, and bioactive docosanoids could be produced from DHA via the same enzymatic pathways as those of PUFA made of 20 carbons. The biosynthesis in the brain of a new mediator formed from enzymatic oxygenation of DHA was recently evidenced in a model of cerebral ischemia and reperfusion in the mouse [108]. The ischemic stroke results in the release of lipoperoxides and cytokines, the increase of COX2 expression and the infiltration of leukocytes. Among the liberated mediators, the authors isolated a new di-hydroxylated compound issued from the oxygenation of DHA by 15-LOX, the $10,17 \mathrm{~S}$-docosatriene, which once isolated and perfused in another animal can strongly inhibit the inflammatory responses induced by the ischemic stroke. According to the authors, this pathway of enzymatic oxygenation of endogenous DHA may contribute to protect the brain against injury produced by oxidising stress. Very recently, they have shown that the $10,17 \mathrm{~S}$-docosatriene molecule, so called "neuroprotectin D1" (NPD1), is synthesised by human retinal pigment epithelial cells treated with a cal- cium ionophore or with DHA [109]. NPD1 added to retinal pigment epithelial cells potently counteracted the apoptotic DNA damage triggered by treatments with oxidative agents. NPD1 also up-regulated the expression of antiapoptotic proteins (Bcl-2 and $\mathrm{Bcl}-\mathrm{xL}$ ), while it decreased those of proapoptotic proteins (Bax, Bad) and $\mathrm{COX} 2$ [109]. Overall, NPD1 protected cells from oxidative stress-induced apoptosis. The NPD1 pathway will very probably lead to new perspectives in research to understand the protective effect of DHA-derived mediators in hypoxic-ischemic situations.

\subsection{PUFA are components of membrane domains}

\subsubsection{Membrane lipids do not mix uniformly}

Since the fluid mosaic model of Singer and Nicholson, the membrane concept has evolved. The protein-protein interactions, within and around the membrane clearly depend on the quality of their lipid microenvironment, and membrane domains ("lipid rafts") have received increasing attention as potential platforms for proteins in signalling and trafficking. The theory of lipid rafts (reviews in $[110,111]$ ) conceptualises that separation of discrete liquid-ordered and liquid-disordered phase domains occurs in membranes containing sufficient amounts of sphingolipids, sterols and saturated phosphatidylcholines. These clusters of ordered lipids are characterised by their insolubility, at low temperature, in nonionic detergents. Then, hydrophobic proteins can be locally packaged with these lipid clusters and be organised as membrane rafts. The organisation, and thus the possibilities for interactions and activations of these lipid raft-interacting proteins, are very different from those of proteins preferentially embedded in the fluid phase, the latter being composed of PUFArich phospholipids having a low degree of order of their acyl chains and allowing a much larger freedom of movement. Studies on artificial membranes have focussed on 
the possible link between DHA, the more unsaturated among structural fatty acids (characterised by a low degree of order within the membrane phospholipids) and the capacity of rhodopsin to receive photons and to transduce them into a biochemical signal.

\subsubsection{Photo-activation of rhodopsin in artificial membranes}

The rhodopsin model perfectly illustrates a category of proteins, whose activity requires rapid and reversible conformational changes, and thus a high flexibility of their membrane environment. Among all membrane proteins of the organism, rhodopsin, located in the membrane disks of the external segment of the cone and rod cells of the retina, is probably the molecule whose immediate lipid environment has the highest DHA concentration (estimated at least one fatty acid out of two). The photoinduced activation of rhodopsin is coupled with the isomerisation of its chromophore, 11-cis-retinal, to an all-trans configuration. Through the cascade activation of a $\mathrm{G}$ protein and of phosphodiesterase, rhodopsin translates the light signal into an electric signal at the origin of visual perception. The photo-activation of one molecule of rhodopsin results in the activation of 1000 to 2000 molecules of phosphodiesterase per second, which provokes the hydrolysis of 100000 molecules of cyclic CMP and the closing off of the ion channels thus blocking within $100 \mathrm{~ms}$ the influx of around one million $\mathrm{Na}^{+}$ions (for a review see [112]). Spectrophotometry methods allow to measure the equilibrium constant (Keq) that rules over the photo-induced conformational changes of rhodopsin. By using artificial membranes of phosphatidylcholine made up of different associations of fatty acids, Litman and Mitchell showed that the Keq value characteristic of native membranes of the retina is only reached in the artificial membrane when it is entirely made up of DHA [113]. The same authors have shown that the incorporation of cholesterol in the phosphatidylcholine membranes (at $30 \mathrm{~mol} \%$ ) also has the effect of reducing the Keq value, and that this inhibitory effect is less pronounced in those membranes that are entirely made up of DHA [114]. In membranes made up of myristic acid (14:0) and of $30 \mathrm{~mol} \%$ cholesterol, a particularly rigid conformation that mimicks lipid rafts, the amount of photoinduced transformation of rhodopsin almost reaches zero [114]. These data prove that DHA is required for the first step of phototransduction and suggest that its abundance in the photoreceptor membranes can be efficiently opposed to the rigidifying effect of cholesterol [115]. The next step of the phototransduction process is binding the photoactivated rhodopsin (metarhodopsin MII) on the Gt subunit of transducin. In artificial membranes, this interaction also depends on the respective proportions of DHA and cholesterol: DHA allows the quasi-instantaneous formation of the MIIGt complex, whereas cholesterol increases the latency time preceding its formation [116]. Altogether, these data prove that the role of DHA in visual perception begins at the initiation step of the phototransduction molecular process. Due to the 6 double bonds of DHA, the ring of membrane phospholipids that encircle rhodopsin can be deformed very rapidly and reversibly, making it thus easier for rhodopsin to change its conformation and to recover its initial state. Finally, the authors used the n-3 deficiency model in the rat to demonstrate that the disk membranes of the n-3 deficient retina, where $80 \%$ of DHA are replaced by $22: 5 n-6$ (n-6 DPA), exhibit a higher degree of order of the phospholipid acyl chains relative to nondeficient rats [117]. The structural change results in reduced rhodopsin activation, rhodopsin-transducin (Gt) coupling, cGMP phosphodiesterase activity, and slower formation of metarhodopsin II (MII) and the MII-Gt complex [117]. These very recent data provide a solid molecular basis for connecting the changes in retinal membrane composition to the reduced amplitude and delayed response of the electroretinogram a-wave observed in $n-3$ chronic deficiency in rodents and nonhuman primates. 


\subsection{Impact of n-3 PUFA deficiency on vesicular neurotransmission}

The synaptic release of neurotransmitters constitutes another membrane process directly implicated in the functioning of the CNS. The process initially concerns the maturation of vesicles carrying neurotransmitters and their storage in the active zone of the presynaptic terminals. The arrival of the action potential causes an influx of calcium that induces the fusion of vesicular and plasma membranes, releasing via exocytosis the neurotransmitters in the synaptic cleft. An opposite process allows to recruit membrane proteins and to regenerate by endocytosis small empty vesicles for a new cycle of maturation and presynaptic storage. The neurotransmitters activate the post-synaptic receptors that translate the entry of calcium ions, permitting the propagation of the action potential within the neuronal network. All functions of the nervous system, from sensorial perception to learning and memory, are governed by the synaptic coupling between exocytosis and endocytosis. The understanding of the complex protein machinery implicated in the vesicular processes has considerably evolved over the last 10 years (review in [118]). The specific role of membrane PUFA in the vesicular processes has been closely studied over the last few years. The use of a chronically $\mathrm{n}-3$ fatty acid deficient rat model has showed the role of n-3 PUFA in the storage and presynaptic releasing processes of several neurotransmitters. The monoaminergic and cholinergic systems have been more specifically studied, due to their implication both in the regulation of important physiological functions and in the control of cognitive processes including attention, motivation and memory. These studies have shown in n-3 deficient rats, an increase in spontaneous release of dopamine in the nucleus accumbens $[119,120]$, acetylcholine [121] or serotonin [122] in the hippocampus (Fig. 6). In contrast, the drug-induced release of these neurotransmitters is significantly reduced $[120,122,123]$. This phe- nomenon could result from an increased basal leakage of the neurotransmitter in the synaptic cleft that would reduce its storage in the vesicles (Fig. 7). During a nervous stimulation, generated for example in a learning situation, the amplitude of neurotransmitter release would then be reduced leading to a lower efficiency of the nervous influx. Concerning the study of the dopaminergic system, it was shown that the n-3 deficiency decreases the number of dopaminergic vesicles in the frontal cortex. These results suggest that n-3 deficiency leads to a hypofunctioning of the mesocortical dopaminergic system, and a model for the general dysfunctioning of the dopaminergic mesocorticolimbic loop has been proposed to explain the behavioural perturbations observed in deficient animals [124]. The membrane deficit in DHA can be one possible explanation of the effects of n-3 deficiency on neurotransmitter storage and release. Besides, modifications caused by n-3 PUFA deficiency in the neurotransmission process could also partly result from alterations in brain energy metabolism, such as glucose utilisation and oxidative phosphorylation [125]. It is therefore assumed that multiple interactions exist among membrane PUFA and vesicular neurotransmission processes, with significant incidences on learning capacity and behaviour.

\subsection{PUFA and their metabolites regulate gene transcription}

\subsubsection{Fatty acids are natural ligands of nuclear receptors}

In 1990, Issemann and Green discovered that molecules used for the treatment of hyperlipidemia act by binding on transcription factors (PPARs, peroxisome proliferators-activated receptors) that belong to the superfamily of steroid hormone receptors [126]. Since it has been shown that fatty acids are natural endogenous activators of PPARs [127], the concept of regulation of biological functions by PUFA and their 


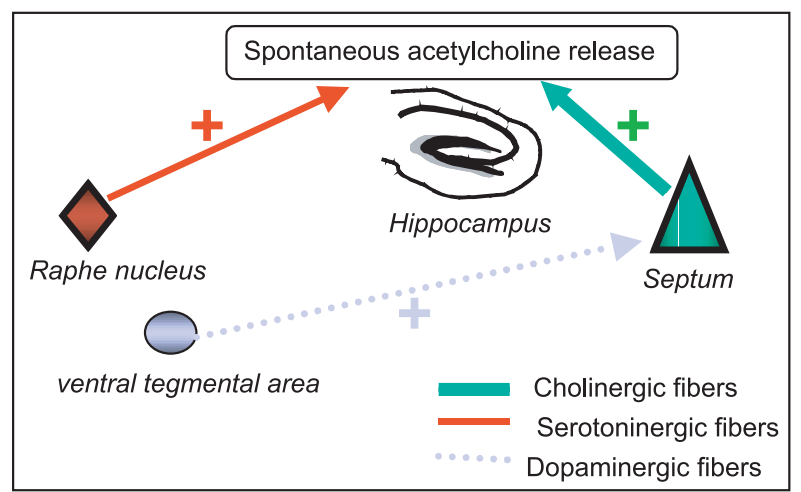

Figure 6. A schematic representation of functional interactions between dopaminergic, serotoninergic and cholinergic neurotransmission systems in the control of Ach release in the hippocampus. In n-3 deficiency, the increase of dopamine synthesis in the ventral tegmental area and the alterations of serotonin release in the hippocampus could participate in the higher spontaneous Ach release (from [120-122]).

oxygenated derivatives has progressed considerably. Binding to PPARs allows fatty acids to partly control their metabolic fate by directly inducing the transcription of genes coding for proteins involved in mitochondrial and peroxisomal $\beta$-oxidation [128]. PPARs interact with responsive elements of the genome made up of two AGGTCA hexamers separated by one base (DR1 repeat) [129]. The genes that possess this type of sequence upstream of their promoter, or a similar sequence, are susceptible to be activated by the transcriptional heterodimer formed by the association of a PPARs with RXR (retinoid receptor) [130]. The PPARs are themselves coded by 3 different genes, differently expressed according to cell type, and translated into 3 isoforms: PPAR $\alpha$, PPAR $\gamma$ and PPAR $\beta / \delta$. RXR also decomposes into 3 isotypes $(\alpha, \beta$ and $\gamma)$. PPAR-RXR heterodimers can also repress the transcription of genes normally activated by other transcription factors by occupying in an inoperative way the target sequence corresponding to their promoters.

A large number of combinations is possible between the different isotypes of PPARs and RXR (including their respective ligands) that may induce varying effects on the target gene transcription level, whether they are directly or indirectly involved in lipid metabolism. The preferential distribution of the PPARs and RXR isotypes in the different tissues and cell types contributes to functional specificities: catabolism of lipids associated with a predominance of PPAR $\alpha$ in the liver, brown adipose tissue and skeletal muscles; differentiation and lipogenesis in the adipose tissue, and uptake of oxidised LDL in macrophages, both preferentially expressing PPAR $\gamma$. The tissue distribution of PPAR $\delta$ is ubiquitous but this isotype is generally more abundant in most of the different cerebral regions [131], the digestive tract, kidneys, heart, diaphragm and oesophagus [132]. In the mouse skeletal muscle, PPAR $\delta$ has been shown to control fatty acid oxidation by regulating genes involved in fatty acid transport, $\beta$-oxidation, and mitochondrial respiration [133, 134].

\subsubsection{PUFA as possible regulators of gene transcription in the CNS}

It is known that transcription of the genes encoding the first two enzymes of the peroxisomal-oxidation pathway, acylCoAoxidase (AOX) and L-peroxisomal bifunctional enzyme (L-PBE), is mediated through the RXR-PPAR heterodimer which binds 


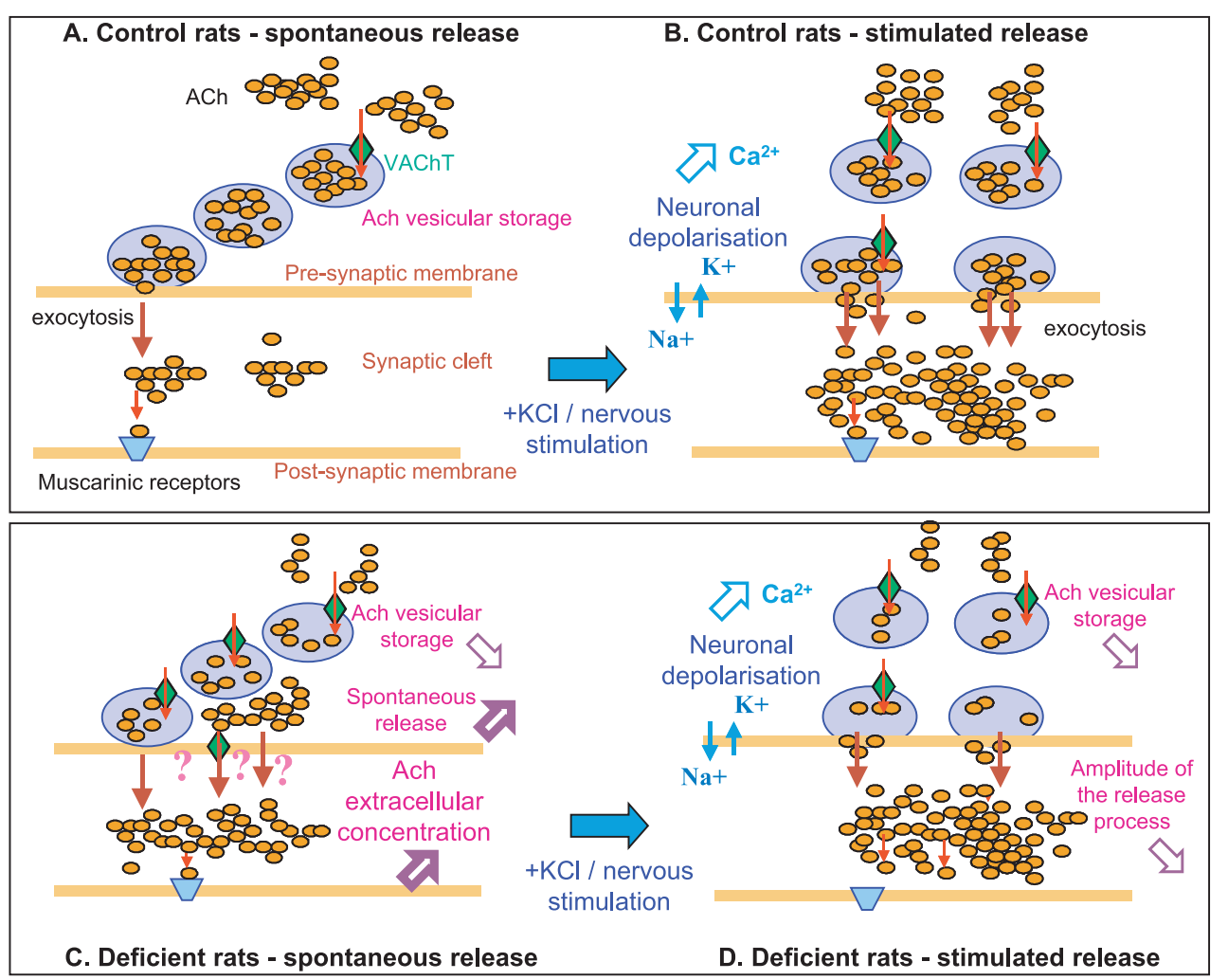

Figure 7. A schematic representation of acetylcholine (Ach) release in the synaptic cleft in resting (spontaneous release) and neuronal activation (stimulated release) conditions, in control (A - B) and n-3 PUFA deficient rats $(C-D)$. In the resting state, a small amount of Ach is released in the extracellular space in control rats (A), whereas this spontaneous release is enhanced in n-3 PUFA deficient rats (C). In stimulated conditions (KCl infusion), cytoplasmic Ach is stored in vesicles through the vesicular Ach transporter (VAVhT). Full vesicles can be recruited for exocytosis and high levels of Ach are released (B). In deficient rats (D), the Ach leakage that occurs in resting conditions leads to storage depletion and then induces reduced Ach release under stimulation (D). 
to the corresponding peroxisome proliferator-responsive elements (PPRE) [130] (AOX initiates the peroxysomal oxidation of the very long-chain fatty acids, allowing the shortening of neurotoxic compounds and the synthesis of DHA from its upstream precursors). However, the specific role of PPARs in the different regions of the CNS, in a possible relation with the regulation of the fatty acid metabolism, is an unresolved question. We have recently made the hypothesis that in retinoblastoma cells, the expression of AOX and the terminal step of DHA synthesis could be regulated by the upstream precursors of DHA through the modulation of PPAR $\delta$-mRNA abundance (PPAR $\delta$ is the major isotype in these cells) [135]. In cultured oligodendrocytes, the chemicallyinduced activation of PPAR $\delta$ favoured the cell morphological differentiation and induced the synthesis of the myelin basic protein, suggesting that PPAR $\delta$ could play a role in nervous conduction by regulating the formation and the maintenance of myelin [136]. Although PUFAs, or some of their metabolites, are likely to exert the role of PPARs ligands in the CNS, the endogenous ligands of the brain PPARs, especially of the $\delta$-isotype, have not been clearly identified.

\subsubsection{The pivotal role of $R X R$}

Actually, it appears that RXR, the obligatory transcriptional partner of PPARs [130], constitutes a very plausible potential target for DHA. This ubiquitous factor regulates the transcription of a large number of genes implicated in the pathways of proliferation, differentiation, and apoptosis in several types of neural cells [137]. RXR $\alpha$ also regulates the transcription of most of the genes implicated in lipid metabolism through its interaction with other transcription factors, such as the constitutive androstane receptor, CAR $\beta$ [138], the retinoic acid receptor, RAR $\alpha$ [139] and the liver X receptors, LXR (also expressed in the rodent brain) [140]. The multiple roles of RXR $\alpha$, a transcription factor positioned at the cross-road of genes encoding for miscellaneous receptors, trans- porters and enzymes of the lipid metabolism, are schematically illustrated in Figure 8.

Finally, the binding of DHA on the ligand binding domain of RXR $\alpha$ has been evidenced in the mouse brain [141], and two recent studies using transfected cells demonstrated that DHA potently activates the transcription of a reporter gene mediated by $\operatorname{RXR} \alpha[142,143]$. These novel data support the concept that DHA, and possibly other PUFA, could activate one or several RXR signalling pathways in the CNS. Therefore, the putative effects of DHA on gene transcription in the brain, possibly recruiting different RXR heterodimers (Fig. 8), and their possible influence on neural function, opens up a large field of investigations.

\subsubsection{PUFA and transcriptional regulations in the CNS: the contribution of microarrays}

Berger et al. studied the effect of dietary long-chain PUFA on the expression of 329 genes in the liver and 356 genes in the hippocampus of mice [144]. One-month-old mice received during 57 days, diets rich in long-chain PUFA (supplementation with fish oil rich in EPA and DHA or a fungal oil rich in AA, or a combination of both). The gene expression profile of these tissues was compared to that of a control diet containing only linoleic and $\alpha$-LNA as PUFA. In the hippocampus, the long-chain n- 6 and n-3 PUFA supplementation affected a category of genes controlling the transthyretin signalling pathway (a transporter of thyroxin in the cerebrospinal liquid), the liberation of serotonin, the functions relative to immunity (immunoglobulins) and the activation of transcriptional factors implicated in inflammation (NFKB). By releasing their fatty acids, certain molecular species of ethanolamine-phosphoglycerides could be at the origin of transcriptional effects specifically induced by n-3 PUFA at the brain level [145-147]. These studies showed that among a panel of 3200 genes screened in the rat brain, the supplementation in $n-3$ 


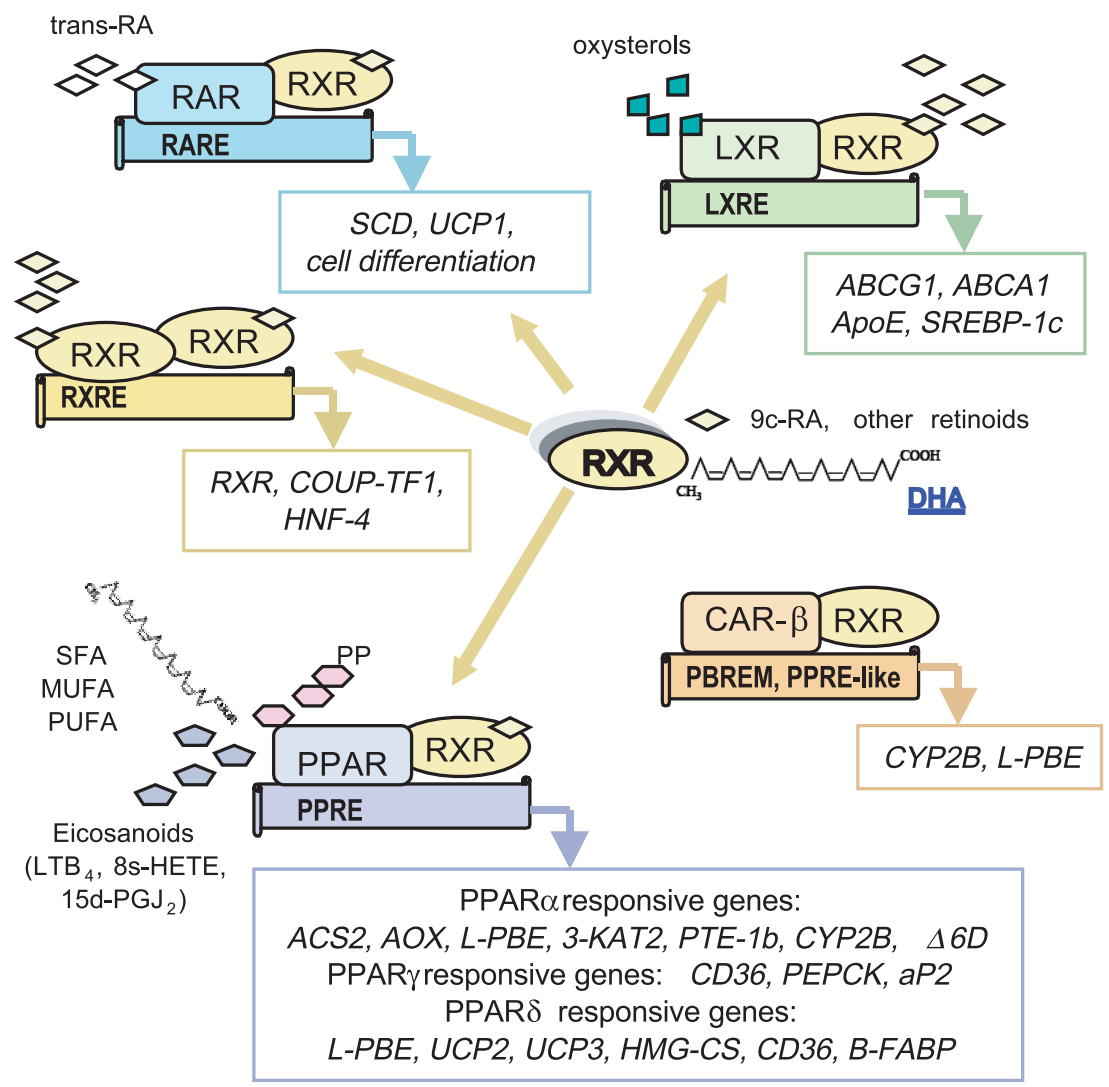

Figure 8. A schematic representation for the multiple gene transcriptions which are potentially activated by the dimer formed by the ligand-induced associations of RXR with one nuclear receptor. The liganded homo- or hetero-dimer binds to a specific DNA sequence, known as a responsive element (RE), i.e. RARE, LXRE, RXRE, PPRE and PBREM, located in the promoter region of the target gene. For simplification, tissue specificity is not considered, corepressors and coactivators of transcription are not represented, and only some examples of the target genes involved in the lipid metabolism are mentioned. By disrupting the interactions between RXR and other nuclear receptors, the ligand-activated PPARs can potentially interfere with the RXR-dependent transcription of multiple genes, notably those coding for lipogenic transcription factors. Fatty acids and some eicosanoids have been identified as natural ligands of PPARs in muscle, hepatic and adipose tissues. According to recent studies, DHA could be an endogenous ligand for RXR in different tissues, including the brain.

long chain PUFA increased the expression of 55 genes and decreased that of 47 genes. The genes affected are involved in synaptic plasticity, signal transduction, ion channel assembly, energetic metabolism and protein regulation. Applying microarrays to 2400 genes expressed in human retinal explants in culture, Rojas et al recently found that the transcription of $14 \%$ of them was significantly increased when the explants were treated with $27 \mu \mathrm{M}$ DHA, whereas only $0.4 \%$ increased upon treatment with oleic acid [148]. Among the genes whose transcription of which was induced by DHA are those playing roles in neurogenesis, neurotransmission and intercellular connections. 
To-date, the pathways of transcriptional activation induced by DHA have not yet been identified.

\section{CONCLUSION}

DHA, which is massively incorporated into the nerve cell membranes, exerts structural and neuroprotective roles that are favourable to the development and maintenance of cerebral and visual performances. EPA, although not stored in the brain cell membranes, can ameliorate diverse psychiatric disorders and probably has roles in brain function, possibly by counteracting the AAmediated signalling. The mechanisms implicated are complex and multiple, reflecting the extraordinary diversity of the functions exercised by the PUFA, going from the modulation of dynamic properties of the membranes to the production of active mediators and the regulation of the expression of genes. The lipid nutrition of the brain, susceptible to influence each of the pathways at each step of life, is thus an essential element of its functioning.

\section{ACKNOWLEDGEMENTS}

We would like to thank Wendy BrandWilliams, INRA (France), for the translation of this paper.

\section{REFERENCES}

[1] Sprecher H. An update on the pathways of polyunsaturated fatty acid metabolism. Curr Opin Clin Nutr Metab Care 1999, 2: 135-138.

[2] Galli D, Agradi E, Paoletti R. The (n-6) pentaene:(n-3) hexaene fatty acid ratio as an index of linolenic acid deficiency. Biochim Biophys Acta 1974, 369: 142-145.

[3] Wheeler TG, Benolken RM, Anderson RE. Visual membranes: specificity of fatty acid precursors for the electrical response to illumination. Science 1975, 188: 1312-1314.

[4] Bourre JM, François M, Youyou A, Dumont O, Piciotti M, Pascal G, Durand G. The effects of dietary $\alpha$-linolenic acid on the composition of nerve membranes, enzymatic activity, amplitude of electrophysiological parameters, resistance to poisons and per- formance of learning tasks in rat. J Nutr 1989, 119: 1880-1892.

[5] Neuringer M, Connor WE, Van Petten C, Barstad L. Dietary $\omega-3$ fatty acid deficiency and visual loss in infant Rhesus monkeys. J Clin Invest 1984, 73: 272-276.

[6] Neuringer M, Connor W, Lin DS, Barstad L, Luck S. Biochemical and functional effects of prenatal and postnatal n-3 fatty acid deficiency on retina and brain in Rhesus monkeys. Proc Natl Acad Sci USA 1986, 83: 4021-4025.

[7] Moriguchi T, Sheaff-Greiner R, Salem N Jr. Behavioral deficits associated with dietary induction of decreased brain docosahexaenoic acid concentration. J Neurochem 2000 , 75: 2563-2573.

[8] Jeffrey BG, Mitchell DC, Gibson RA, Neuringer M. n-3 Fatty acid deficiency alters recovery of the rod photoresponse in Rhesus monkeys. Invest Ophthalmol Vis Sci 2002, 43: 28062814.

[9] Connor WE, Neuringer M. The effects of n3 fatty acid deficiency and repletion upon the fatty acid composition and function of the brain and retina. Prog Clin Biol Res 1988, 282: 275-294.

[10] Diau GY, Loew ER, Wijendran V, SarkadiNagy E, Nathanielsz PW, Brenna JT. Docosahexaenoic and arachidonic acid influence on preterm baboon retinal composition and function. Invest Ophthalmol Vis Sci 2003, 44: 4559-4566.

[11] Uauy RD, Birch DG, Birch EE, Tyson JE, Hoffman DR. Effect of dietary $\omega-3$ fatty acids on retinal function of very-low-birth-weight neonates. Pediatr Res 1990, 28: 485-492.

[12] Birch D, Birch E, Hoffman D, Uauy R. Retinal development in very-low-birth-weight infants fed diets differing in $\omega$-3 fatty acids. Invest Ophthalmol Vis Sci 1992, 33: 23652376.

[13] Birch E, Birch D, Hoffman D, Hale L, Everett M, Uauy R. Breast-feeding and optimal visual development. J Pediatr Ophthalmol Strabismus 1993, 30: 33-38.

[14] Lauritzen L, Hansen HS, Jùrgensen $M H$, Michaelsen KF. The essentiality of long chain n-3 fatty acids in relation to development and function of the brain and retina. Prog Lipid Res 2001, 4: 1-94.

[15] Makrides M, Neumann MA, Byard RW, Simmer K, Gibson RA. Fatty acid composition of brain, retina, and erythrocytes in breast- and formula-fed infants. Am J Clin Nutr 1994, 60: 189-194.

[16] Birch EE, Garfield S, Hoffman DR, Uauy R, Birch DG. A randomized controlled trial of early dietary supply of long-chain polyunsaturated fatty acids and mental development in 
term infants. Dev Med Child Neurol 2000, 42: 174-181.

[17] Hoffman DR, Birch EE, Castaneda YS, Fawcett SL, Wheaton DH, Birch DG, Uauy $\mathrm{R}$. Visual function in breast-fed term infants weaned to formula with or without longchain polyunsaturates at 4 to 6 months: a randomized clinical trial. J Pediatr 2003, 142: 669-677.

[18] Connor W, Neuringer M, Reisbick S. Essential fatty acids: the importance of n-3 fatty acids in the retina and brain. Nutr Rev 1992, 50: 21-29.

[19] Salem N Jr, Wegher B, Mena P, Uauy R. Arachidonic and docosahexaenoic acids are biosynthesized from their 18 -carbon precursors in human infants. Proc Natl Acad Sci USA, 1996, 93: 49-54.

[20] Uauy R, Mena P, Wegher B, Nieto S, Salem $\mathrm{N}$ Jr. Long chain polyunsaturated fatty acid formation in neonates: effect of gestational age and intrauterine growth. Pediatr Res 2000, 47: 127-135.

[21] Pawlosky RJ, Hibbeln JR, Novotny JA, Salem N Jr. Physiological compartmental analysis of $\alpha$-linolenic acid metabolism in adult humans. J Lipid Res 2001, 42: 1257 1265.

[22] Maurage C, Guesnet P, Pinault M, Rochette de Lempdes J, Durand G, Antoine J, Couet C. Effect of two types of fish oil supplementation on plasma and erythrocyte phospholipids in formula-fed term infants. Biol Neonate 1998, 74: 416-429.

[23] Cunnane SC, Francescutti V, Brenna JT, Crawford MA. Breast-fed infants achieve a higher rate of brain and whole body docosahexaenoate accumulation than formula-fed infants not consuming dietary docosahexaenoate. Lipids 2000, 35: 105-111.

[24] Gibson RA, Neumann MA, Makrides M. Effect of increasing breast milk docosahexaenoic acid on plasma and erythrocyte phospholipid fatty acids and neural indices of exclusively breast fed infants. Eur J Clin Nutr 1997, 51: 578-584.

[25] Guesnet P, Antoine J-M, Rochette de Lempdes J-B, Galent A, Durand G. Polyunsaturated fatty acid composition of human milk in France: changes during the course of lactation and regional differences. Eur J Clin Nutr 1993, 47: 700-710.

[26] Alessandri JM, Goustard B, Guesnet P, Durand G. Polyunsaturated fatty acids status in blood, heart, liver, intestine, retina and brain of newborn piglets fed either sow milk or a milk replacer diet. Reprod Nutr Dev 1996, 36: 95-109.
[27] Goustard-Langelier B, Guesnet P, Durand G, Antoine JM, Alessandri JM. n-3 and n-6 fatty acid enrichment by dietary fish oil and phospholipid sources in brain cortical areas and nonneural tissues of formula-fed piglets. Lipids 1999, 34: 5-16.

[28] Alessandri JM, Goustard B, Guesnet P, Durand G. Docosahexaenoic acid concentrations in retinal phospholipids of piglets fed an infant formula enriched with long-chain polyunsaturated fatty acids: effects of egg phospholipids and fish oils with different ratios of eicosapentaenoic acid to docosahexaenoic acid. Am J Clin Nutr 1998, 67: 377-385.

[29] Alessandri JM, Poumès-Ballihaut C, Langelier B, Perruchot MH, Raguénez G, Lavialle M, Guesnet P. Incorporation of docosahexaenoic acid into nerve membrane phospholipids: bridging the gap between animals and cultured cells. Am J Clin Nutr 2003, 78: 702-710.

[30] Legrand P, Bourre JM, Descomps B, Durand G, Renaud S. Lipides. In: Martin A (Ed), Apports nutritionnels conseillés pour la population française, AFSSA $3^{\mathrm{e}} \mathrm{ed}$, Tec \& Doc, 2001, p 63-82.

[31] Beaufrère B, Briend A, Ghisolfi J, Goulet $O$, Putet G, Rieu D, Turck D, Vidailhet M. Nourrissons, enfants et adolescents. In: Martin A (Ed), Apports nutritionnels conseillés pour la population française, AFSSA $3^{\mathrm{e}}$ ed, Tec \& Doc, 2001, p 255-291.

[32] Galli C. Commentary on the workshop statement. Essentiality of and recommended dietary intake of Omega-6 and Omega-3 fatty acids. Prostaglandins Leukot Essent Fat Acids 2000, 63: 127-129.

[33] Simopoulos AP, Leaf A, Salem N Jr. Workshop statement on the essentiality of and recommended dietary intakes for Omega-6 and Omega-3 fatty acids. Prostaglandins Leukot Essent Fat Acids 2000, 63: 119-121.

[34] Innis SM. Human milk and formula fatty acids. J Pediatr 1992, 120: S56-S61.

[35] Guesnet P, Couet C, Alessandri JM, Antoine JM, Durand G. Variabilité de la teneur en acide linoléique $(18: 2 n-6)$ et du rapport 18:2n-6/18:3n-3 des lipides dans le lait de femme en France. Ann Pédiatr (Paris) 1995, 42: 282-288.

[36] Chulei R, Xiaofang L, Hongsheng M, Xiulan M, Guizheng L, Gianhong D, DeFrancesco CA, Connor WE. Milk composition in women from five different regions of China: the great diversity of milk fatty acids. J Nutr 1995, 125: 2993-299.

[37] Combes N, Boué C. Apports alimentaires en acides linoléique et $\alpha$-linolénique d'une population aquitaine. OCL 2001, 8: 118-121. 
[38] Djoussé L, Hunt SC, Arnett DK, Province MA, Eckfeldt JH, Ellison RC. Dietary linolenic acid is inversely associated with plasma triacylglycerol: the National Heart, Lung, and Blood Institute Family Heart Study. Am J Clin Nutr 2003, 78: 1098-1102.

[39] Meyer BJ, Mann NJ, Lewis JL, Milligan GC, Sinclair AJ, Howe PR. Dietary intakes and food sources of omega- 6 and omega- 3 polyunsaturated fatty acids. Lipids 2003, 38:391398.

[40] Voskuil DW, Feskens EJM, Katan MB, Kromhout D. Intake and sources of $\alpha$-linolenic acid in Dutch elderly men. Eur J Clin Nutr 1996, 50: 784-787.

[41] Johansson LRK, Solvoll K, Bjornboe GEA, Drevon CA. Intake of very long-chain n-3 fatty acids related to social status and lifestyle. Eur J Clin Nutr 1998, 52: 716-721.

[42] Astorg P, Arnault N, Czernichow S, Noisette N, Galan P, Hercberg S. Dietary intakes and food sources of n-6 and n-3 polyunsaturated fatty acids in French adult men and women. Lipids (in press).

[43] Welch AA, Lund E, Amiano P, Dorronsoro M, Brustad M, Kumle M et al. Variability of fish consumption within the 10 European countries participating in the European Investigation into Cancer and Nutrition (EPIC) study. Public Health Nutr 2002, 5: 1273-1285.

[44] Hulshof KFAM, van Erp-Baart MA, Anttolainen M, Becker W, Church SM, Couet C, Hermann-Kunz E, Kesteloot H, Leth T, Martins I. Intake of fatty acids in Western Europe with emphasis on trans fatty acids: the TRANSFAIR study. Eur J Clin Nutr 1999, 53: 143-157.

[45] Adams PB, Lawson S, Sanigorski A, Sinclair AJ. Arachidonic acid to eicosapentaenoic acid ratio in blood correlates positively with clinical symptoms of depression. Lipids 1996, 31 (Suppl): S157-S161.

[46] Maes M, Smith R, Christophe A, Cosyns P, Desnyder R, Meltzer H. Fatty acid composition in major depression: decreased $\omega 3$ fractions in cholesteryl esters and increased C20:4 $\omega 6 / \mathrm{C} 20: 5 \omega 3$ ratio in cholesteryl esters and phospholipids. J Affect Disord 1996, 38 : 35-46.

[47] Peet M, Murphy B, Shay J, Horrobin D. Depletion of omega-3 fatty acid levels in red blood cell membranes of depressive patients. Biol Psychiatry 1998, 43: 315-319.

[48] Edwards R, Peet M, Shay J, Horrobin D. Omega-3 polyunsaturated fatty acid levels in the diet and in red blood cell membranes of depressed patients. J Affect Disord 1998, 48: 149-155.
[49] Maes M, Christophe A, Delanghe J, Altamura C, Neels H, Meltzer HY. Lowered $\omega 3$ polyunsaturated fatty acids in serum phospholipids and cholesteryl esters of depressed patients. Psychiatry Res 1999, 85: 275-291.

[50] De Vriese SR, Christophe AB, Maes M. Lowered serum n-3 polyunsaturated fatty acid (PUFA) levels predict the occurrence of postpartum depression: further evidence that lowered n-3PUFAs are related to major depression. Life Sci 2003, 73: 3181-3187.

[51] Ranjekar PK, Hinge A, Hegde MV, Ghate M, Kale A, Sitasawad S, Wagh UV, Debsikdar VB, Mahadik SP. Decreased antioxidant enzymes and membrane essential polyunsaturated fatty acids in schizophrenic and bipolar mood disorder patients. Psychiatry Res 2003, 121: 109-122.

[52] Chiu CC, Huang SY, Su KP, Lu ML, Huang MC, Chen CC, Shen WW. Polyunsaturated fatty acid deficit in patients with bipolar mania. Eur Neuropsychopharmacol 2003, 13: 99-103.

[53] Glen AIM, Glen EMT, Horrobin DF, Vaddadi KS, Spellman M, Morsefisher N, Ellis K, Shinner FS. A red cell membrane abnormality in a subgroup of schizophrenic patients: evidence for two diseases. Schizophr Res 1994, 12: 53-61.

[54] Peet M, Laugharne J, Rangarajan N, Horrobin D, Reynolds G. Depleted red cell membrane essential fatty acids in drug-treated schizophrenic patients. J Psychiatr Res 1995, 29: 227-232.

[55] Fenton WS, Hibbeln J, Knable M. Essential fatty acids, lipid membrane abnormalities, and the diagnosis and treatment of schizophrenia. Biol Psychiatry 2000, 47: 8-21.

[56] Khan MM, Evans DR, Visayasudha G, Scheffer RE, Parikh VV, Mahadik SP. Reduced erythrocyte membrane essential fatty acids and increased lipid peroxides in schizophrenia at the never-medicated first episode of psychosis and after years of treatment with antipsychotics. Schizophr Res 2002, 58: 1-10.

[57] Arvindakshan M, Sitasawads S, Debsikdar V, Ghate M, Evans D, Horrobin DF, Bennett C, Ranjekar PK, Mahadik SP. Essential polyunsaturated fatty acid and lipid peroxide levels in never-medicated and medicated schizoprenia patients. Biol Psychiatry 2003, 53: 56-64.

[58] Burgess JR, Stevens L, Zhang W, Peck L. Long-chain polyunsaturated fatty acids in children with attention-deficit hyperactivity disorder. Am J Clin Nutr 2000, 71: 327S$330 \mathrm{~S}$.

[59] Vancassel S, Durand G, Bartélémy C, Lejeune $\mathrm{B}$, Martineau J, Guilloteau D, Andrès C, Chalon S. Plasma fatty acid levels in autistic 
children. Prostaglandins Leukot Essent Fat Acids 2001, 65: 1-7.

[60] Hibbeln JR. Fish consumption and major depression. Lancet 1998, 351: 1213.

[61] Hibbeln JR. Seafood consumption, the DHA content of mothers' milk and prevalence rates of postpartum depression: a cross-national, ecological analysis. J Affect Disord 2002, 69: $15-29$.

[62] Noaghiul S, Hibbeln JR. Cross-national comparisons of seafood consumption and rates of bipolar disorders. Am J Psychiatry 2003, 160: 2222-2227.

[63] Hirayama T. Life-style and mortality: a large census-based cohort study in Japan. Ed Karger, Basel, 1990.

[64] Huan M, Hamazaki K, Sun Y, Itomura M, Liu H, Kang W, Watanabe S, Terasawa K, Hamazaki T. Suicide attempt and n-3 fatty acid levels in red blood cells: a case-control study in China. Biol Psychiatry 2004, 56: 490-496.

[65] Tanskanen A, Hibbeln JR, Hintikka J, Haatainen K, Honkalampi K, Viinamaki H. Fish consumption, depression, and suicidality in a general population. Arch Gen Psychiatry 2001, 58: 512-513.

[66] Tanskanen A, Hibbeln JR, Tuomilehto J, Uutela A, Haukkala A, Viinamaki H, Lehtonen J, Vartiainen E. Fish consumption and depressive symptoms in the general population in Finland. Psychiatr Serv 2001, 52: 529-531.

[67] Silvers KM, Scott KM. Fish consumption and self-reported physical and mental health status. Public Health Nutr 2002, 5: 427-431.

[68] Timonen M. Horrobin D, Jokelainen J, Laitinen J, Herva A, Räsänen P. Fish consumption and depression: the Northern Finland 1966 birth cohort study. J Affect Disord 2004, 82: 447452.

[69] Suzuki S, Akechi T, Kobayashi M, Taniguchi K, Goto K, Sasaki S, Tsugane S, Nishiwaki Y, Miyaoka H, Uchitomi Y. Daily omega-3 fatty acid intake and depression in Japanese patients with newly diagnosed lung cancer. Br J Cancer 2004, 90: 787-793.

[70] Mamalakis G, Tornaritis M, Kafatos A. Depression and adipose essential polyunsaturated fatty acids. Prostaglandins Leukot Essent Fat Acids 2002, 6: 311-318.

[71] Mamalakis G, Kiriakakis M, Tsibinos G, Kafatos A. Depression and adipose polyunsaturated fatty acids in the survivors of the seven countries study population of Crete. Prostaglandins Leukot Essent Fat Acids 2004, 70: 495-501.

[72] Tiemeyer H, van Thuil HR, Hofman A, Kiliaan AJ, Breteler MMB. Plasma fatty acid composition and depression are associated in the elderly: the Rotterdam Study. Am J Clin Nutr 2003, 78: 40-46.
[73] Hakkarainen R, Partonen T, Haukka J, Virtamo J, Albanes D, Lonnqvist J. Is low dietary intake of omega-3 fatty acids associated with depression? Am J Psychiatry 2004, 161: 567-569.

[74] Nemets B, Stahl Z, Belmaker RH. Addition of omega-3 fatty acid to maintenance medication treatment for recurrent unipolar depressive disorder. Am J Psychiatry 2002, 159: 477-479.

[75] Peet M, Horrobin DF. A dose-ranging study of the effects of ethyl-eicosapentaenoate in patients with ongoing depression despite apparently adequate treatment with standard drugs. Arch Gen Psychiatry 2002, 59: 913 919.

[76] Post RM, Leverich GS, Altshuler LL, Frye MA, Suppes TM, Keck PE Jr, McElroy SL, Kupka R, Nolen WA, Grunze H, Walden J. An overview of recent findings of the Stanley Foundation Bipolar Network (Part I). Bipolar Disord 2003, 5: 310-319.

[77] Stoll AL, Severus WE, Freeman MP, Rueter S, Zboyan HA, Diamond E, Cress KK, Marangell LB. Omega 3 fatty acids in bipolar disorder: a preliminary double-blind, placebo-controlled trial, Arch Gen Psychiatry 1999, 56: 407-412.

[78] Su KP, Huang SY, Chiu CC, Shen WW. Omega-3 fatty acids in major depressive disorder: a preliminary double-blind, placebocontrolled trial. Eur Neuropsychopharmacol 2003, 13: 267-271.

[79] Zanarini MC, Frankenburg MD. Omega-3 fatty acid treatment of women with borderline personality disorder: a double-blind, placebo-controlled pilot study. Am J Psychiatry 2003, 160: 167-169.

[80] Marangell LB, Martinez JM, Zboyan HA, Kertz B, Kim HF, Puryear LJ. A double-blind, placebo-controlled study of the omega-3 fatty acid docosahexaenoic acid in the treatment of major depression. Am J Psychiatry 2003, 160: 996-998.

[81] Llorente AM, Jensen CL, Voigt RG, Fraley JK, Berretta MC, Heird WC. Effect of maternal docosahexaenoic acid supplementation on postpartum depression and information processing. Am. J Obstet Gynecol 2003, 188: 1348-1353.

[82] Peet M, Brind J, Ramchand CN, Shah S, Vankar GK. Two double-blind placebo-controlled pilot studies of eicosapentaenoic acid in the treatment of schizophrenia. Schizophr Res 2001, 49: 243-251.

[83] Peet M, Horrobin DF, in association with the E-E Multicentre Study Group. A dose-ranging exploratory study of the effects of ethyleicosapentaenoate in patients with persistent schizophrenic symptoms. J Psychiatr Res 2002, 36: 7-18. 
[84] Emsley RA, Myburgh CC, Oosthuizen PP, Van Rensburgh SJ. Randomised placebocontrolled study of ethyl-eicosapentaenoic acid as supplemental treatment in schizophrenia. Am J Psychiatry 2002, 159: 15961598.

[85] Richardson AJ, Puri BK. A randomized double-blind, placebo-controlled study of the effects of supplementation with highly unsaturated fatty acids on ADHD-related symptoms in children with specific learning difficulties. Prog Neuropsychopharmacol Biol Psychiatr 2002, 26: 233-239.

[86] Ayton AK, Azaz A, Horrobin DF. A pilot open case series of ethyl-EPA supplementation in the treatment of anorexia nervosa. Prostaglandins Leukot Essent Fat Acids 2004, 71: 205-209.

[87] Horrobin DF, Jenkins K, Bennett CN, Christie WW. Eicosapentaenoic acid and arachidonic acid: collaboration and not antagonism is the key to biological understanding. Prostaglandins Leukot Essent Fat Acids 2002, 66: 83-89.

[88] Conquer JA, Tierney MC, Zecevic J, Bettger WJ, Fisher RH. Fatty acid analysis of blood plasma of patients with Alzheimer's disease, other types of dementia, and cognitive impairment. Lipids 2000, 35: 1305-1312.

[89] Tully AM, Roche HM, Fallon C, Bruce I, Lawlor B, Coakley D, Gibney MJ. Low serum cholesteryl ester-docosahexaenoic acid levels in Alzheimer's disease: a casecontrol study. Br J Nutr 2003, 89: 483-489.

[90] Heude B, Ducimetière P, Berr C. Cognitive decline and fatty acid composition of erythrocyte membranes - The EVA Study. Am J Clin Nutr 2003, 77: 803-808.

[91] Kalmijn S, van Boxtel MPJ, Ocke M, Verschuren WMM, Kromhout D, Launer LJ. Dietary intake of fatty acids and fish in relation to cognitive performance at middle age. Neurology 2004, 62: 275-280.

[92] Kalmijn S, Launer LJ, Ott A, Witteman JCM, Hofman A, Breteler MB. Dietary fat intake and the risk of incident dementia in the Rotterdam study. Ann Neurol 1997, 62: 275280.

[93] Morris MC, Evans DA, Bienias JL, Tangney CC, Bennett DA, Wilson RS, Aggarwal N, Schneider J. Consumption of fish and n-3 fatty acids and risk of incident Alzheimer disease. Arch Neurol 2003, 60: 940-946.

[94] Barberger-Gateau P, Letenneur L, Deschamps V, Pérès K, Dartigues JF, Renaud S. Fish, meat, and risk of dementia: cohort study. $\mathrm{Br}$ Med J 2002, 325: 932-933.

[95] Nordvik I, Myhr KM, Nyland H, Bjerve KS. Effect of dietary advice and n-3 supplemen- tation in newly diagnosed MS patients. Acta Neurol Scand 2000, 102: 143-149.

[96] Schlanger S, Shinitsky M, Yam D. Diet enriched with omega-3 fatty acids alleviates convulsion symptoms in epilepsy patients. Epilepsia 2002, 43: 103-104.

[97] Puri BK, Bydder GM, Counsell SJ, Corridan BJ, Richardson AJ, Hajnal JV, Appel C, Mckee HM, Vaddadi KS, Horrobin DF. MRI and neuropsychological improvement in Huntington disease following ethyl-EPA treatment. Neuroreport 2002, 13: 123-126.

[98] Hashimoto M, Hossain S, Shimada T, Sugioka K, Yamasaki H, Fujii Y, Ishibashi Y, Oka JI, Shido O. Docosahexaenoic acid provides protection from impairment of learning ability in Alzheimer's disease model rats. J Neurochem 2002, 81: 1084-1091.

[99] Bazan NG. Synaptic lipid signaling: significance of polyunsaturated fatty acids and platelet-activating factor. J Lipid Res 2003, 44: 2221-2233.

[100] Blanc EM, Keller JN, Fernandez S, Mattson MP. 4-Hydroxynonenal, a lipid peroxidation product, impairs glutamate transport in cortical astrocytes. Glia 1998, 22: 149-160.

[101] Tong W, Shah D, Xu J, Diehl JA, Hans A, Hannink M, Sun GY. Involvement of lipid mediators on cytokine signaling and induction of secretory phospholipase A2 in immortalized astrocytes (DITNC). J Mol Neurosci 1999, 12: 89-99.

[102] Jump DB. The biochemistry of $n-3$ polyunsaturated fatty acids. J Biol Chem 2002, 277 : 8755-8758.

[103] Petroni A, Salami M, Blasevich M, Papini N, Galli C. Inhibition by n-3 fatty acids of arachidonic acid metabolism in a primary culture of astroglial cells. Neurochem Res 1994, 19: 1187-1193.

[104] Gordon-Bell J, Tocher DR, Sargent JR. Effect of supplementation with 20:3(n-6), 20:4(n-6) and 20:5(n-3) on the production of prostaglandins $\mathrm{E}$ and $\mathrm{F}$ of the 1-, 2- and 3-series in turbot (Scophthalmus maximus) brain stroglial cells in primary culture. Biochem Biophys Acta 1994, 1211: 335-342.

[105] Galli C, Marangoni F, Petroni A. Modulation of arachidonic acid metabolism in cultured rat astroglial cells by long-chain n-3 fatty acids. Adv Exp Med Biol 1992, 318: 115-120.

[106] Champeil-Potokar G, Denis I, GoustardLangelier B, Alessandri JM, Guesnet P, Lavialle M. Astrocytes in culture require docosahexaenoic acid to restore the $n-3 / n-6$ polyunsaturated fatty acid balance in their membrane phospholipids. J Neurosci Res 2004, 75: 96106. 
[107] Newman EA. New roles for astrocytes: regulation of synaptic transmission. Trends Neurosci 2003, 26: 536-542.

[108] Marcheselli VL, Hong S, Lukiw WJ, Tian XH, Gronert K, Musto A, Hardy M, Gimenez JM, Chiang N, Serhan CN, Bazan NG. Novel docosanoids inhibit brain ischemia-reperfusion-mediated leukocyte infiltration and pro-inflammatory gene expression. J Biol Chem 2003, 278: 43807-43817.

[109] Mukherjee PK, Marcheselli VL, Serhan CN, Bazan NG. Neuroprotectin D1: a docosahexaenoic acid-derived docosatriene protects human retinal pigment epithelial cells from oxidative stress. Proc Natl Acad Sci USA 2004, 101: 8491-8496.

[110] Lee A. Membrane structure. Curr Biol 2001, 11: R811-R814.

[111] Mayor S, Rao M. Rafts: scale-dependent, active lipid organization at the cell surface. Traffic 2004, 5: 231-240.

[112] DeMar JC Jr, Rundle DR, Wensel TG, Anderson RE. Heterogeneous N-terminal acylation of retinal proteins. Prog Lipid Res 1999, 38: 49-90.

[113] Litman BJ, Mitchel DC. A role for phospholipid polyunsaturation in modulating membrane protein function. Lipids 1996, 31S: S193-S197.

[114] Litman BJ, Niu SL, Polozova A, Mitchell DC. The role of docosahexaenoic acid containing phospholipids in modulating $\mathrm{G}$ protein-coupled signaling pathways: visual transduction. J Mol Neurosci 2001, 16: 237 242.

[115] Polozova A, Litman BJ. Cholesterol dependent recruitment of di22:6-PC by a $\mathrm{G}$ proteincoupled receptor into lateral domains. Biophys J 2000, 79: 2632-2643.

[116] Mitchell DC, Niu SL, Litman BJ. Optimization of receptor-G protein coupling by bilayer lipid composition I. Kinetics of rhodopsintransducin binding. J Biol Chem 2001, 276 : 42801-42806.

[117] Niu SL, Mitchell DC, Lim SY, Wen ZM, Kim HY, Salem N Jr, Litman BJ. Reduced G protein-coupled signaling efficiency in retinal rod outer segments in response to n-3 fatty acid deficiency. J Biol Chem 2004, 279 . 31098-31104.

[118] Yao PJ. Synaptic frailty and clathrin-mediated synaptic vesicle trafficking in Alzheimer's disease. Trends Neurosci 2004, 27: 24-29.

[119] Zimmer L, Delion-Vancassel S, Durand G, Guilloteau D, Bodard S, Besnard JC, Chalon $\mathrm{S}$. Modification of dopamine neurotransmission in the nucleus accumbens of rats defi- cient in $\mathrm{n}-3$ polyunsaturated fatty acids. $\mathrm{J}$ Lipid Res 2000, 41: 32-40.

[120] Zimmer L, Vancassel S, Cantagrel S, Breton P, Delamanche S, Guilloteau D, Durand G, Chalon S. The dopamine mesocorticolimbic pathway is affected by deficiency in n-3 polyunsaturated fatty acids. Am J Clin Nutr 2002 , 75: 662-667.

[121] Aïd S, Vancassel S, Poumès-Ballihaut C, Chalon S, Guesnet P, Lavialle M. Effect of a dietinduced (n-3) polyunsaturated fatty acid depletion on cholinergic parameters in the rat hippocampus. J Lipid Res 2003, 44: 1545-1551.

[122] Kodas E, Galineau L, Bodard S, Vancassel S, Guilloteau D, Besnard JC, Chalon S. Serotoninergic neurotransmission is affected by $\mathrm{n}-3$ polyunsaturated fatty acids in the rat. $\mathrm{J}$ Neurochem 2004, 89: 695-702.

[123] Delion S, Chalon S, Herault J, Guilloteau D, Besnard JC, Durand G. Chronic dietary $\alpha$ linolenic acid deficiency alters dopaminergic and serotoninergic neurotransmission in rats. J Nutr 1994, 124: 2466-2476.

[124] Chalon S, Vancassel S, Zimmer L, Guilloteau D, Durand G. Polyunsaturated fatty acids and cerebral function: focus on monoaminergic neurotransmission. Lipids 2001, 36: $937-$ 944.

[125] Ximenes da Silva A, Lavialle F, Gendrot G Guesnet P, Alessandri JM, Lavialle M. Glucose transport and utilization are altered in the brain of rats deficient in $n-3$ polyunsaturated fatty acids. J Neurochem 2002, 81: 1328-1337.

[126] Issemann I, Green S. Activation of a member of the steroid hormone receptor superfamily by peroxisome proliferators. Nature 1990, 347: 645-650.

[127] Kliewer SA, Sundseth SS, Jones SA, Brown PJ, Wisely GB, Koble CS, Devchand P, Wahli W, Willson TM, Lenhard JM, Lehmann JM. Fatty acids and eicosanoids regulate gene expression through direct interactions with peroxisome proliferator-activated receptors alpha and gamma. Proc Natl Acad Sci USA 1997, 94: 4318-4323.

[128] Zhang B, Marcus SL, Sajjadi FG, Alvares K, Reddy JK, Subramani S, Rachubinski RA, Capone JP. Identification of a peroxisome proliferator-responsive element upstream of the gene encoding rat peroxisomal enoylCoA hydratase/3-hydroxyacyl-CoA dehydrogenase. Proc Natl Acad Sci USA 1992, 89: 7541-7545.

[129] Desvergne B, Ijpenberg A, Devchand PR, Wahli W. The peroxisome proliferator-activated receptors at the cross-road of diet and hormonal signalling. J Steroid Biochem Mol Biol 1998, 65: 65-74. 
[130] Marcus SL, Miyata KS, Zhang B, Subramani S, Rachubinski RA, Capone JP. Diverse peroxisome proliferator-activated receptors bind to the peroxisome proliferator-responsive elements of the rat hydratase/dehydrogenase and fatty acyl-CoA oxidase genes but differentially induce expression. Proc Natl Acad Sci USA 1993, 90: 5723-5727.

[131] Moreno S, Farioli-Vecchioli S, Cerù MP. Immunolocalization of peroxisome proliferator-activated receptors and retinoid X receptors in the adult rat CNS. Neuroscience 2004, 123: 131-145.

[132] Escher P, Braissant O, Basu-Modak S, MichalikL, Wahli W, Desvergne B. Rat PPARs: quantitative analysis in adult rat tissues and regulation in fasting and refeeding. Endocrinology 2001, 142: 4195-4202.

[133] Holst D, Luquet S, Nogueira V, Kristiansen K, Leverve X, Grimaldi PA. Nutritional regulation and role of peroxisome proliferatoractivated receptor $\delta$ in fatty acid catabolism in skeletal muscle. Biochim Biophys Acta Mol Cell Biol Lipids 2003, 1633: 43-50.

[134] Tanaka T, Yamamoto J, Iwasaki S, Asaba H, Hamura H, Ikeda Y, Watanabe M, Magoori K, Ioka RX, Tachibana K, Watanabe Y, Uchiyama Y, Sumi K, Iguchi H, Ito S, Doi T, Hamakubo T, Naito M, Auwerx J, Yanagisawa M, Kodama T, Sakai J. Activation of peroxisome proliferator-activated receptor $\delta$ induces fatty acid $\beta$-oxidation in skeletal muscle and attenuates metabolic syndrome. Proc Natl Acad Sci USA 2003, 100: 15924-15929.

[135] Langelier B, Furet JP, Perruchot MH, Alessandri JM. Docosahexaenoic acid membrane content and mRNA expression of acyl-CoA oxidase and of peroxisome proliferator-activated receptor- $\sigma$ are modulated in Y79 retinoblastoma cells differently by low and high doses of $\alpha$-linolenic acid. J Neurosci Res 2003, 74: 134-141.

[136] Saluja I, Granneman JG, Skoff RP. PPAR delta agonists stimulate oligodendrocyte differentiation in tissue culture. Glia 2001, 33: 191-204.

[137] McCaffery PJ, Adams J, Maden M, RosaMolinar E. Too much of a good thing: retinoic acid as an endogenous regulator of neural differentiation and exogenous teratogen. Eur J Neurosci 2003, 18: 457-472.

[138] Kassam A, Winrow CJ, Fernandez-Rachubinski F, Capone JP, Rachubinski RA. The peroxisome proliferator response element of the gene encoding the peroxisomal-oxidation enzyme enoyl-CoA hydratase/3-hydroxyacyl-CoA dehydrogenase is a target for constitutive androstane receptor/9-cis-retinoic acid receptor-mediated transactivation. J Biol Chem 2000, 275: 4345-4350.
[139] Samuel W, Kutty RK, Nagineni S, Gordon JS, Prouty SM, Chandraratna RAS, Wiggert B. Regulation of stearoyl coenzyme A desaturase expression in human retinal pigment epithelial cells by retinoic acid. J Biol Chem 2001, 276: 28744-28750.

[140] Whitney KD, Watson MA, Collins JL, Benson WG, Stone TM, Numerick MJ, Tippin TK, Wilson JG, Winegar DA, Kliewer SA. Regulation of cholesterol homeostasis by the liver $\mathrm{X}$ receptors in the central nervous system. Mol Endocrinol 2002, 16: 1378-1385.

[141] Mata de Urquiza M, Liu S, Sjoberg M, Zetterstrom RH, Griffiths W, Sjovall J, Perlmann T. Docosahexaenoic acid, a ligand for the retinoid $\mathrm{X}$ receptor in mouse brain. Science 2000, 290: 2140-2144.

[142] Fan YY, Spencer TE, Wang N, Moyer MP, Chapkin RS. Chemopreventive n-3 fatty acids activate RXR $\alpha$ in colonocytes. Carcinogenesis 2003, 24: 1541-1548.

[143] Lengqvist J, De Urquiza AM, Bergman AC, Wilson TM, Sjovall J, Perlmann T, Griffiths WJ. Polyunsaturated fatty acids including docosahexaenoic and arachidonic acid bind to the retinoid $\mathrm{X}$ receptor alpha ligand binding domain. Mol Cell Proteomics 2004, 3: 692-703.

[144] Berger A, Mutch DM, German JB, Roberts MA. Dietary effects of arachidonate-rich fungal oil and fish oil on murine hepatic and hippocampal gene expression. Lipids Health Dis 2002, 1: 1-23.

[145] Kitajka K, Puskas LG, Zvara A, Hackler L, Barcelo-Coblijn G, Yeo YK, Farkas T. The role of n-3 polyunsaturated fatty acids in brain: modulation of rat brain gene expression by dietary n-3 fatty acids. Proc Natl Acad Sci USA 2002, 99: 2619-2624.

[146] Barcelo-Coblijn G, Kitajka K, Puskas LG, Hogyes E, Zvara A, Hackler L, Farkas T. Gene expression and molecular composition of phospholipids in rat brain in relation to dietary n-6 to n-3 fatty acid ratio. Biochim Biophys Acta 2003, 1632: 72-79.

[147] Bracelo-Coblijn G, Hogyes E, Kitajka K, Puskas LG, Zvara A, Hacker L, Nyakas C, Penke Z, Farkas T. Modification by docosahexaenoic acid of age-induced alterations in gene expression and molecular composition of rat brain phospholipids. Proc Natl Acad Sci USA 2003, 100: 11321-11326.

[148] Rojas CV, Martinez JI, Flores I, Hoffman DR, Uauy R. Gene expression analysis in human fetal retinal explants treated with docosahexaenoic acid. Invest Ophthalmol Vis Sci 2003, 44: 3170-3177. 